\title{
Distribution and Host Range of Ranaviruses
}

\author{
Amanda L.J. Duffus, Thomas B. Waltzek, Anke C. Stöhr, \\ Matthew C. Allender, Michael Gotesman, Richard J. Whittington, \\ Paul Hick, Megan K. Hines, and Rachel E. Marschang
}

\section{Introduction}

The genus Ranavirus is a group of globally emerging pathogens infecting fish, amphibians, and reptiles, impacting both captive and wild animals. Ranaviruses are pathogens capable of infecting multiple species at a site (e.g., Mao et al. 1999a;

\footnotetext{
A.L.J. Duffus $(\bowtie)$

Department of Biology, Gordon State College, Barnesville, GA, USA

e-mail: aduffus@gordonstate.edu
}

T.B. Waltzek • M. Gotesman

Department of Infectious Diseases and Pathology, College of Veterinary Medicine,

University of Florida, Gainesville, FL, USA

e-mail: tbwaltzek@ufl.edu; mgotesman@ufl.edu

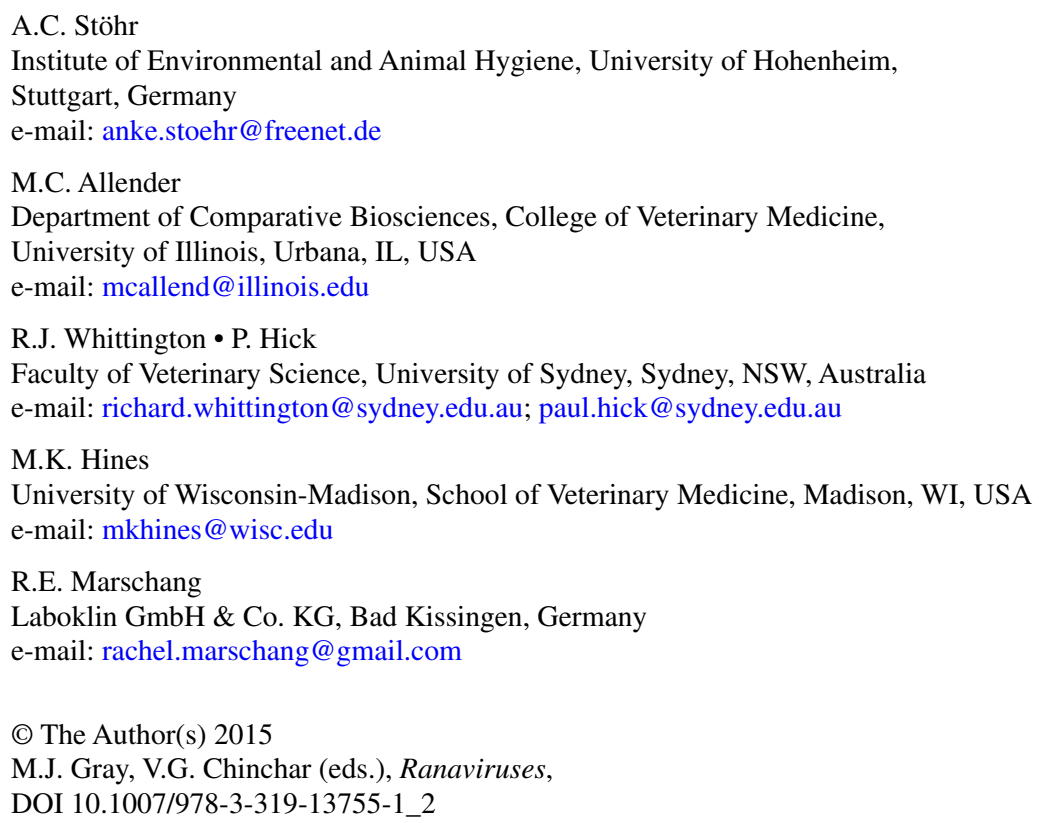


Duffus et al. 2008), and can be transmitted between taxonomic classes of ectothermic vertebrates (e.g., Brenes et al. 2014a, b; Brunner et al. 2015). Ranaviruses are known to infect at least 175 species across 52 families of ectothermic vertebrates, and are found on all continents but Antarctica (Table 1; Figs. 1 and 2). Most of what is known

Table 1 The taxonomic distribution of ranavirus cases among amphibian, fish, and reptilian hosts

\begin{tabular}{|c|c|c|}
\hline & Family & No. species affected \\
\hline \multirow[t]{18}{*}{ Amphibians } & Alytidae & 1 \\
\hline & Ambystomatidae & $8^{\mathrm{a}}$ \\
\hline & Bufonidae & 8 \\
\hline & Centrolenidae & 1 \\
\hline & Craugastoridae & 3 \\
\hline & Cryptobranchidae & 2 \\
\hline & Dendrobatidae & 5 \\
\hline & Hylidae & 15 \\
\hline & Hynobiidae & 1 \\
\hline & Leptodactylidae & $2^{\mathrm{a}}$ \\
\hline & Megophryidae & 1 \\
\hline & Myobatrachidae & 2 \\
\hline & Pipidae & 1 \\
\hline & Plethodontidae & 21 \\
\hline & Ranidae & $22^{\mathrm{a}}$ \\
\hline & Rhacophoridae & 1 \\
\hline & Salamandridae & 8 \\
\hline & Scaphiopodidae & 1 \\
\hline \multirow[t]{22}{*}{ Fish } & Acipenseridae & 3 \\
\hline & Anguillidae & 1 \\
\hline & Centrarchidae & 9 \\
\hline & Channidae & 1 \\
\hline & Catostomidae & 1 \\
\hline & Cyprinidae & 2 \\
\hline & Eleotridae & 1 \\
\hline & Esocidae & 2 \\
\hline & Gadidae & 1 \\
\hline & Gasterosteidae & 1 \\
\hline & Ictaluridae & 2 \\
\hline & Labridae & 1 \\
\hline & Latidae & 1 \\
\hline & Lutjanidae & 1 \\
\hline & Moronidae & 3 \\
\hline & Percidae & 2 \\
\hline & Poeciliidae & 1 \\
\hline & Salmonidae & 1 \\
\hline & Sciaenidae & 1 \\
\hline & Scophthalmidae & 1 \\
\hline & Serranidae & 4 \\
\hline & Siluridae & 1 \\
\hline
\end{tabular}

(continued) 
Table 1 (continued)

\begin{tabular}{l|l|l}
\hline & Family & No. species affected \\
\hline \multirow{4}{*}{ Reptiles } & Agamidae & 2 \\
\cline { 2 - 3 } & Anguidae & 1 \\
\cline { 2 - 3 } & Boidae & 1 \\
\cline { 2 - 3 } & Dactyloidae & 2 \\
\cline { 2 - 3 } Emydidae & 4 \\
\cline { 2 - 3 } & Gekkonidae & 1 \\
\cline { 2 - 3 } & Iguanidae & 1 \\
\cline { 2 - 3 } & Lacertidae & 2 \\
\cline { 2 - 3 } & Pythonidae & 4 \\
\cline { 2 - 3 } & Testudinidae & 8 \\
\cline { 2 - 3 } & Trionychidae & 1 \\
\cline { 2 - 3 } & Varanidae & 1 \\
\hline
\end{tabular}

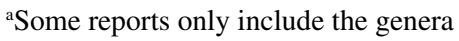

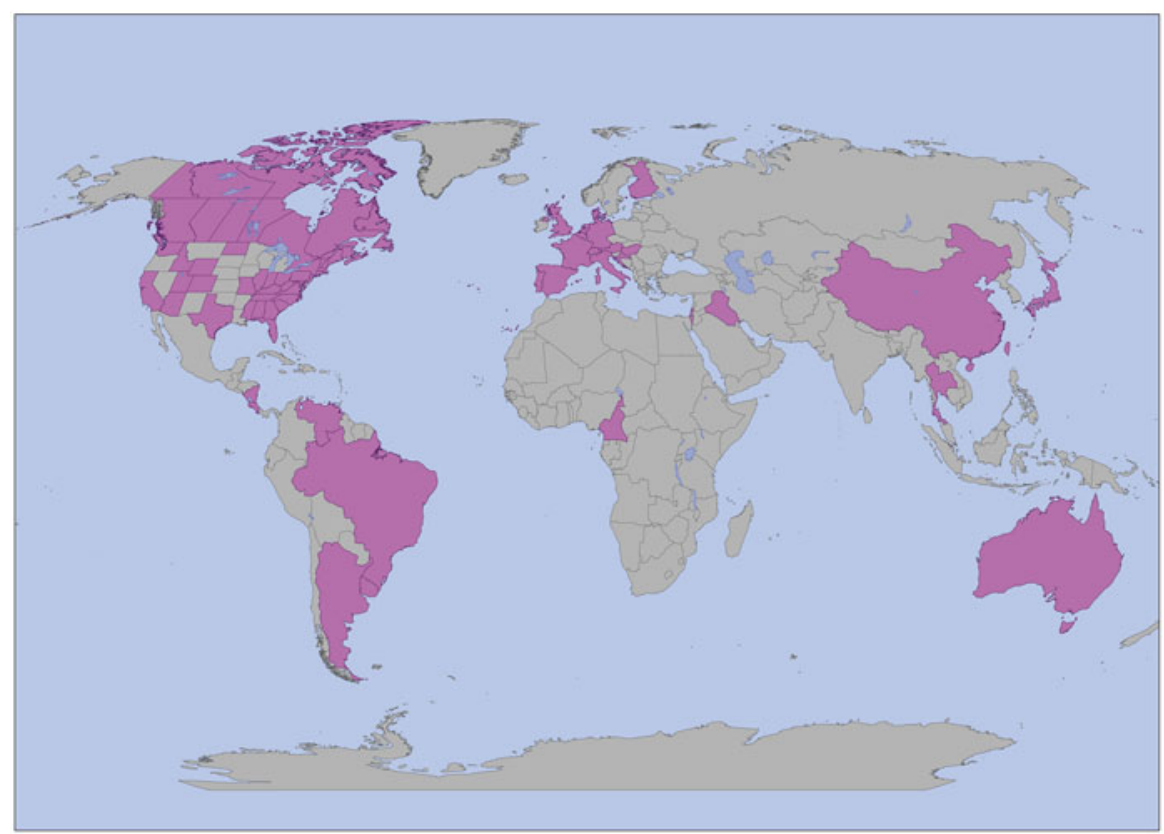

Fig. 1 Global distribution of ranavirus cases

about the epidemiology, geography, and host range of ranaviruses comes from investigations of obvious die-offs, sporadic surveillance efforts in small numbers of populations at one or two time points, and a few larger-scale surveillance efforts focused on a handful of species of economic importance or conservation interest (Grizzle and Brunner 2003; Gray et al. 2009b; Whittington et al. 2010; Miller et al. 2011; Gray et al. 2015). Because gross signs of infection may not be displayed, many host species are cryptic and difficult to detect, the lack of awareness of ranaviruses as significant pathogens, and occasional misdiagnosis, the known geographic distribution and host range of ranaviruses are likely underestimated. 

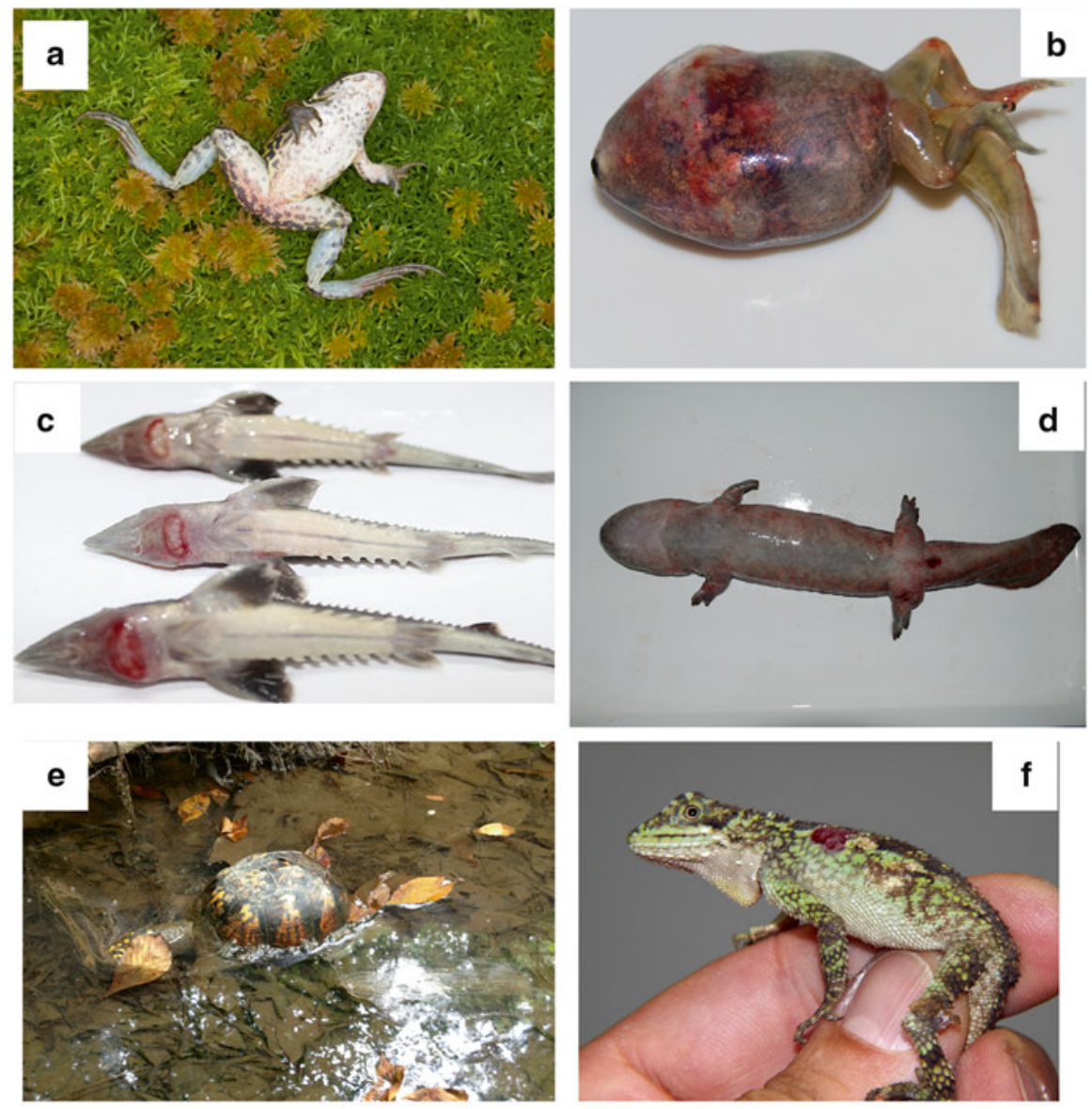

Fig. 2 Ranaviruses are known to cause disease in three ectothermic vertebrate classes. (a) Dead adult edible frog (Rana esculenta) in the Netherlands (credit=Jeiger Herder), (b) morbid plains spadefoot (Spea bombifrons) in the USA (credit=Drew Davis), (c) infected Amur sturgeon (Acipenser schrenckii) in China (credit $=$ Yi Geng), $(\mathbf{d})$ morbid juvenile Chinese giant salamander (Andrias davidianus) in China (credit=Lingbing Zeng), (e) dead eastern box turtle (Terrapene carolina carolina) in the USA (credit=Matthew Allender), and $(\mathbf{f})$ infected green striped tree dragon (Japalura splendida) with ranavirus-associated dermatitis in Germany (credit=Helge Behncke)

Ranaviruses are classified as emerging pathogens, because their geographic distribution and host range appear to be expanding (Daszak et al. 1999). It is becoming evident that ranaviruses are frequently moved in the regional and international trade of animals. For example, barred tiger salamander (Ambystoma mavortium) larvae are sold as fishing bait in the southwestern USA, and as many as $100 \%$ have been shown to be infected with the ranavirus, Ambystoma tigrinum virus (ATV; Picco and Collins 2008; Brunner et al. 2015). Amphibian ranaviruses have been found in animals that are traded over international borders for a variety of reasons, including human consumption and the pet trade (Schloegel et al. 2009; Kolby et al. 2014). Schloegel et al. (2009) found that $8.5 \%$ of amphibians imported into the USA at three major port 
cities were infected with ranavirus. Similarly, Kolby et al. (2014) found over $50 \%$ of amphibians exported via Hong Kong International Airport were infected with ranavirus. Reptiles infected with ranaviruses also have been discovered in internationally traded animals (Hyatt et al. 2002; Stöhr et al. 2013b, 2015). Finally, internationally traded ornamental fishes have been shown to be infected with ranaviruses (Hedrick and McDowell 1995).

While the outcome of infection varies among hosts and strains of ranaviruses, it is clear that ranaviruses have the potential to cause population declines and extinctions (Teacher et al. 2010; Price et al. 2014; Earl and Gray 2014). They may present a significant threat to host species that are geographically isolated or exist at low abundance (Heard et al. 2013; Price et al. 2014; Earl and Gray 2014). Thus, highly susceptible host species that are rare may be at greatest risk (Earl and Gray 2014). However, common species also can be affected. For example, populations of the common frog (Rana temporaria) have declined on average $80 \%$ in the UK where ranavirus die-offs have reoccurred (Teacher et al. 2010). It is therefore important to understand the geographic extent, host range, and phylogenetic relationships of these emerging pathogens (Jancovich et al. 2015).

\section{Ranaviruses Infecting Amphibians}

The first ranaviruses were isolated from northern leopard frogs (Lithobates pipiens) from the Midwest USA in the 1960s (Granoff et al. 1965; Clark et al. 1968). One of these viruses, isolated from a frog with adenocarcinoma, was designated Frog virus 3 (FV3; Granoff et al. 1965), and became the type species of the genus, Ranavirus. While many aspects of FV3 virology were well characterized in the following decades (Chinchar 2002), there were few reports of ranaviral disease associated with amphibians so the pathogen received little attention. A second species of Ranavirus, Bohle iridovirus (BIV), was not isolated from amphibians until the early 1990s. This virus was detected in captive animals in Australia (Speare and Smith 1992). About the same time, epizootic die-offs were being recorded in the southwestern USA and the UK (Collins et al. 1988; Cunningham et al. 1993), but it was not until the mid-1990s that the etiology of the disease was determined to be a ranavirus (Drury et al. 1995; Cunningham et al. 1996; Jancovich et al. 1997, Fig. 2). Reports of ranavirus-related mortality and infection in amphibians have grown exponentially, with over $90 \%$ of reports occurring after 2010. Although greater awareness and more surveillance for the pathogen have impacted this trend, the increase in ranavirus cases is likely not solely a sampling artifact. We now realize that the distribution of amphibian ranaviruses is global, and die-offs are occurring in places where these viruses were previously undetected.

Ranaviruses have a global distribution (Fig. 1; Table 2), and have been identified as threats to amphibian populations (e.g., Duffus and Cunningham 2010; Teacher et al. 2010; Miller et al. 2011). Amphibian ranaviruses have been reported in at least 105 species of amphibians in 18 families in 25 countries (Fig. 3; Table 2). These numbers are likely underestimated because many amphibians are cryptic in nature or rare, gross signs 


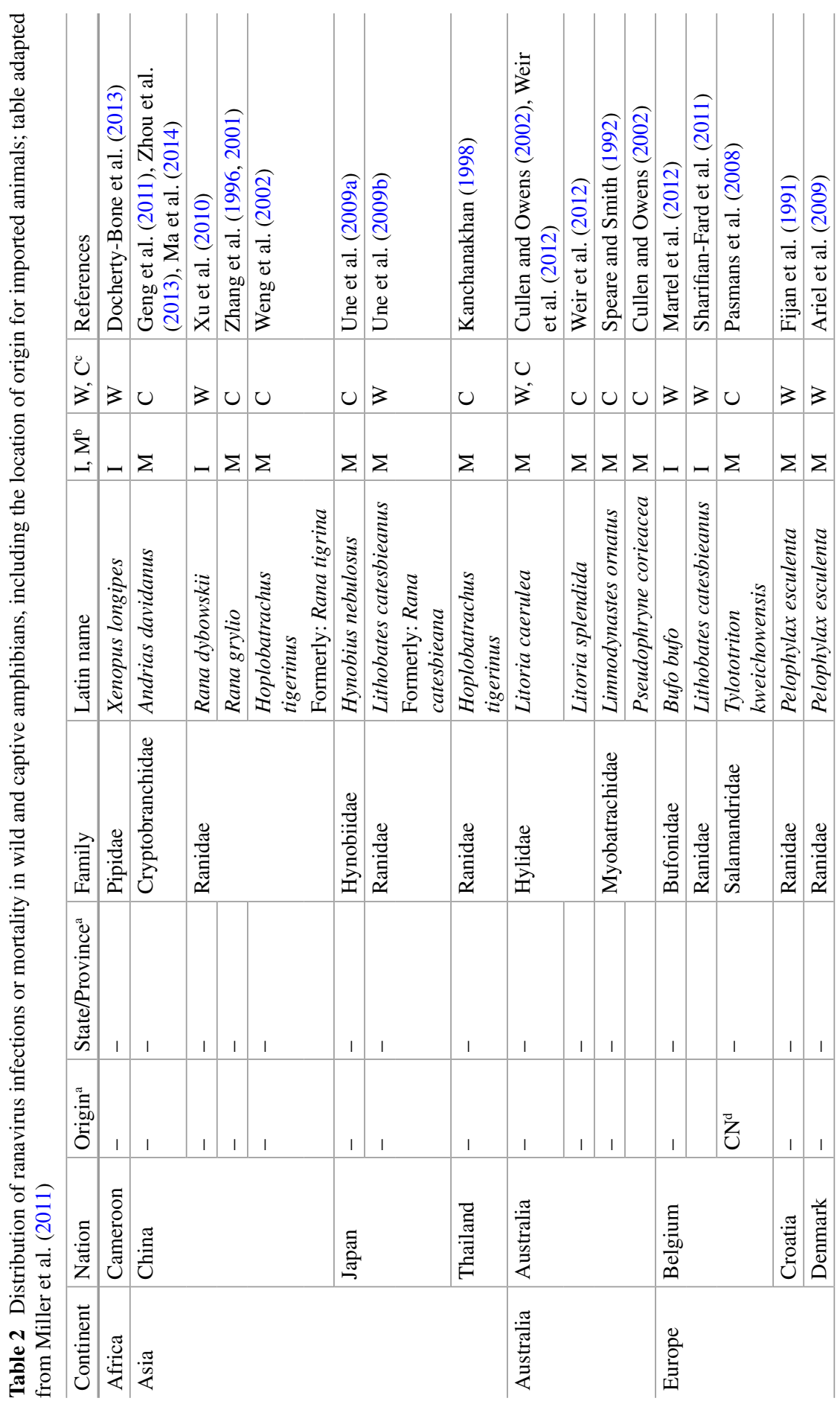




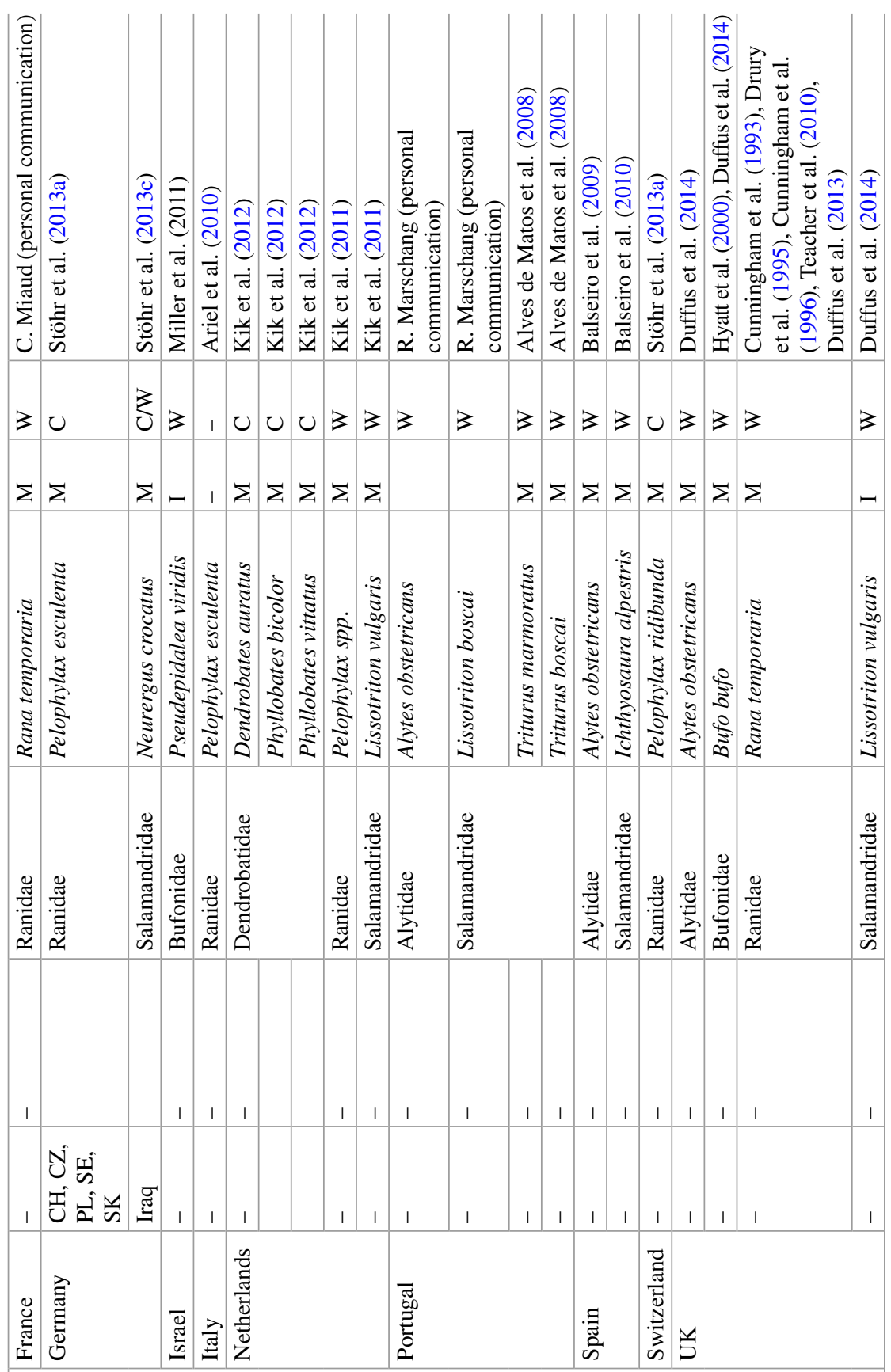




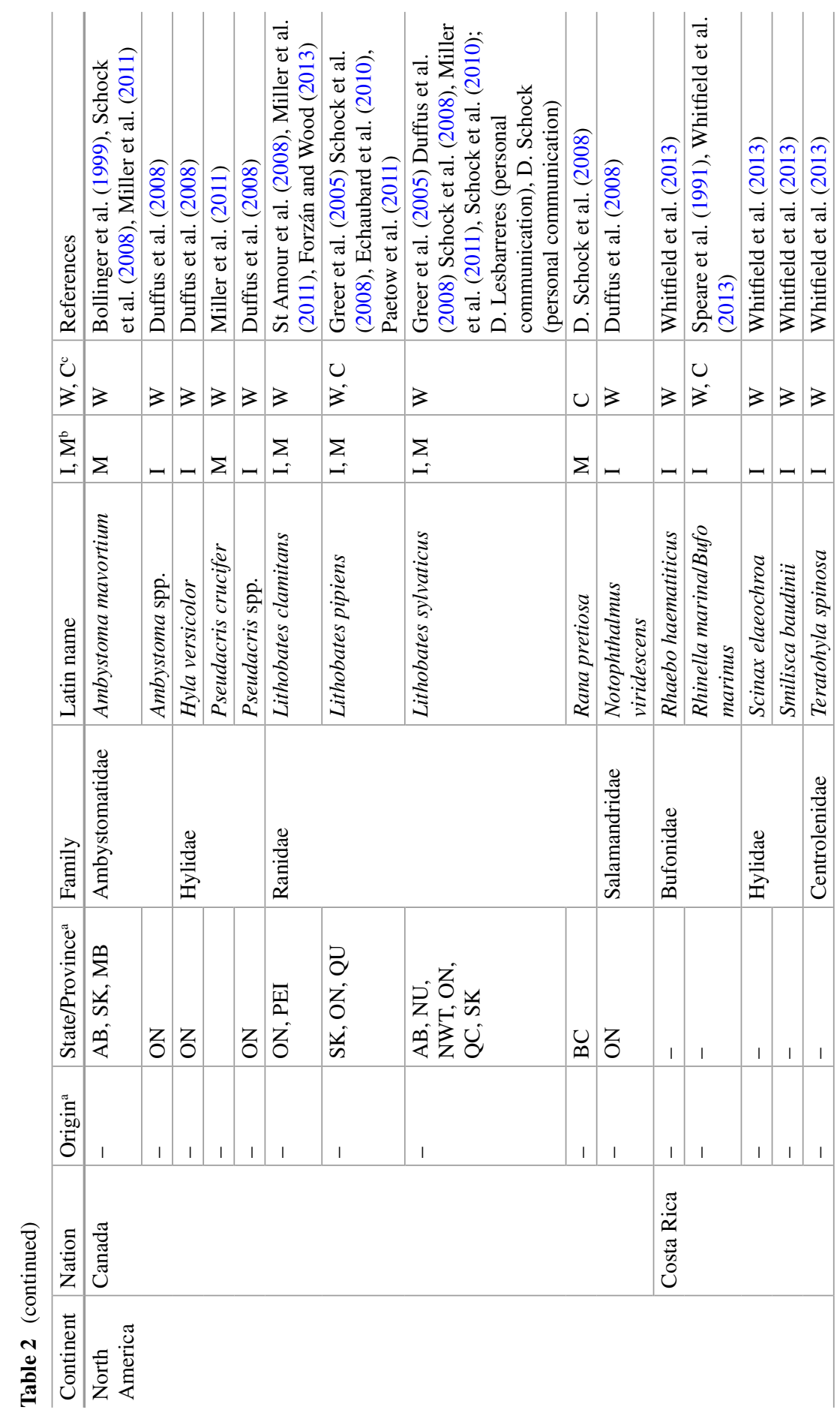




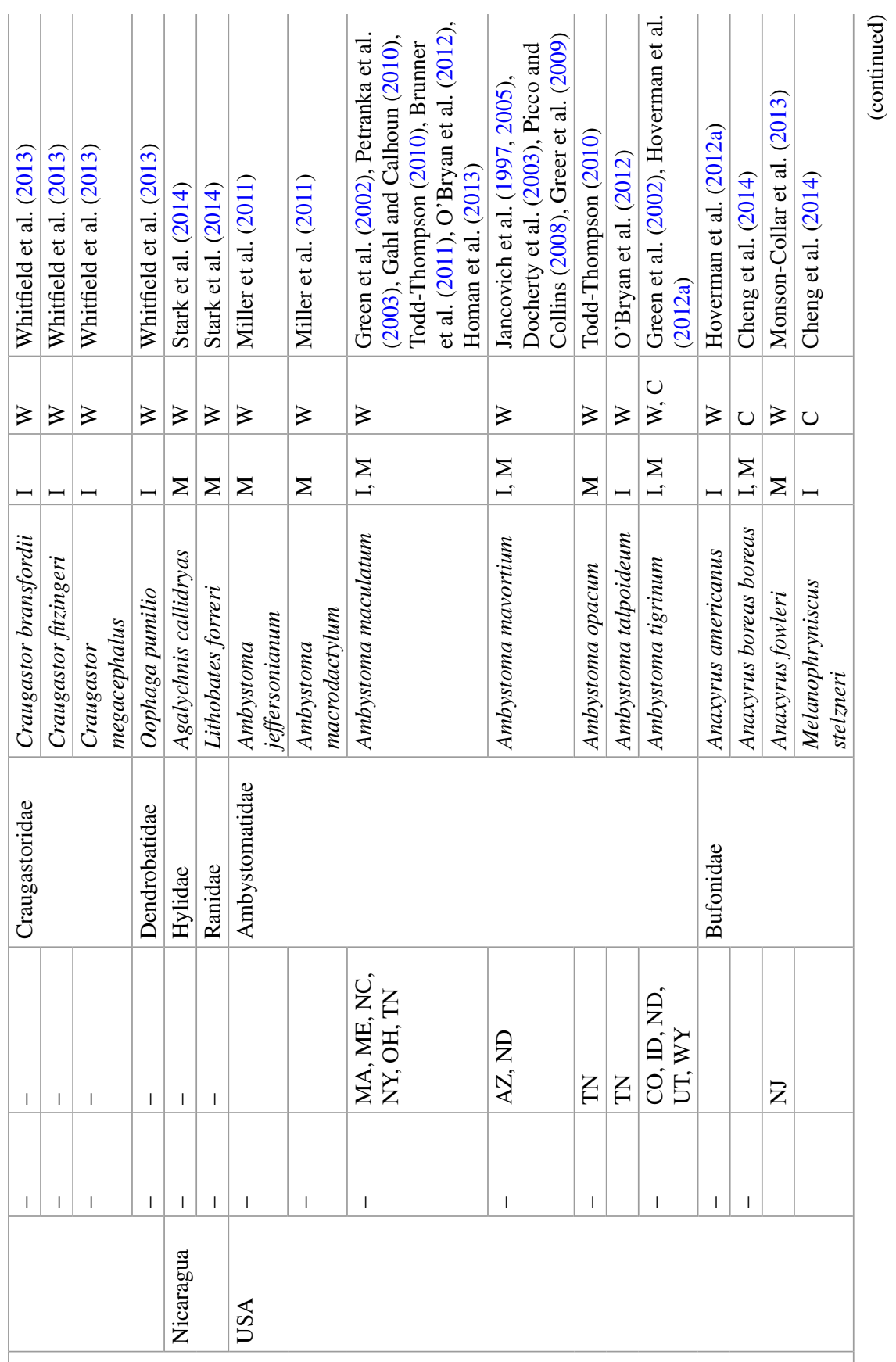




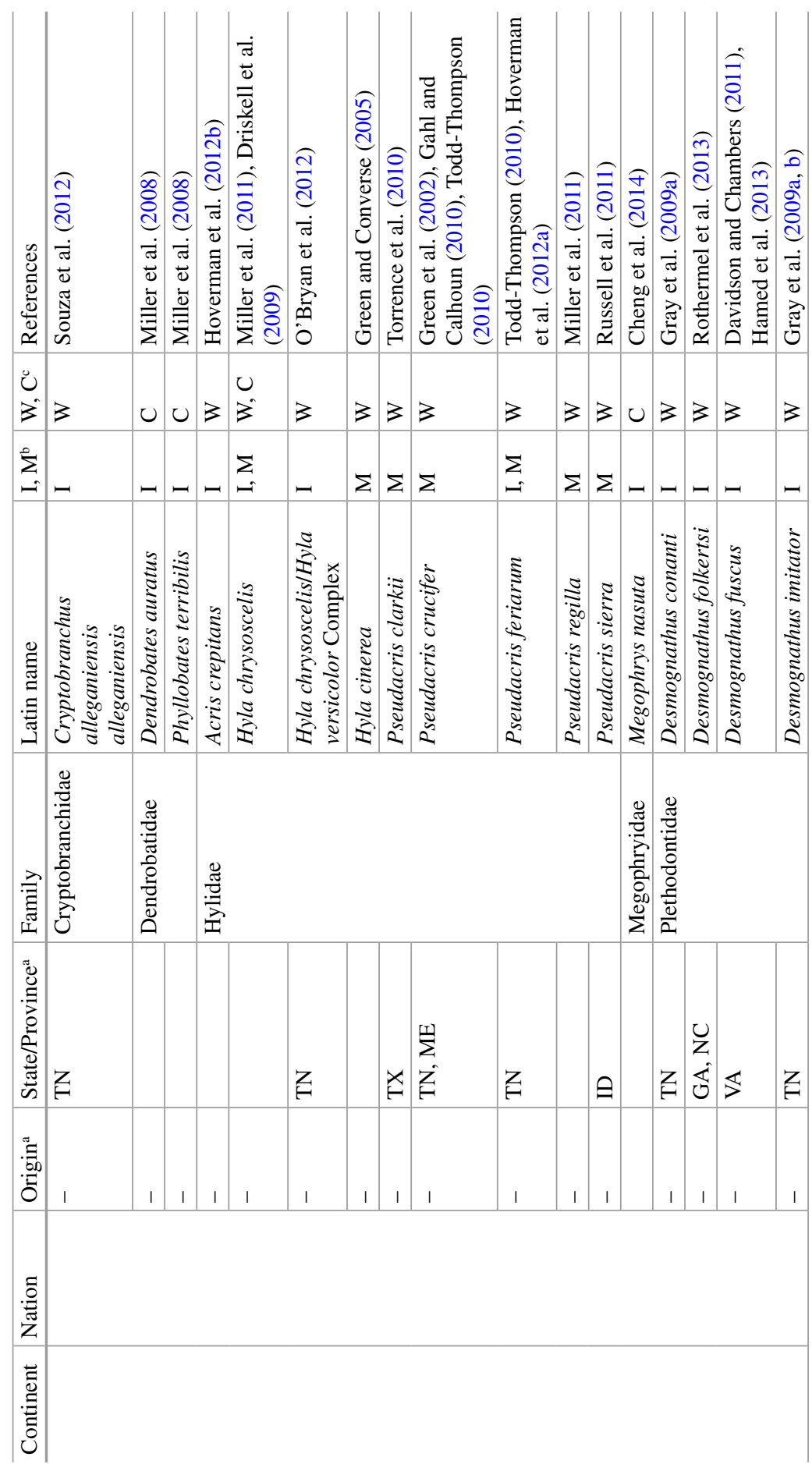




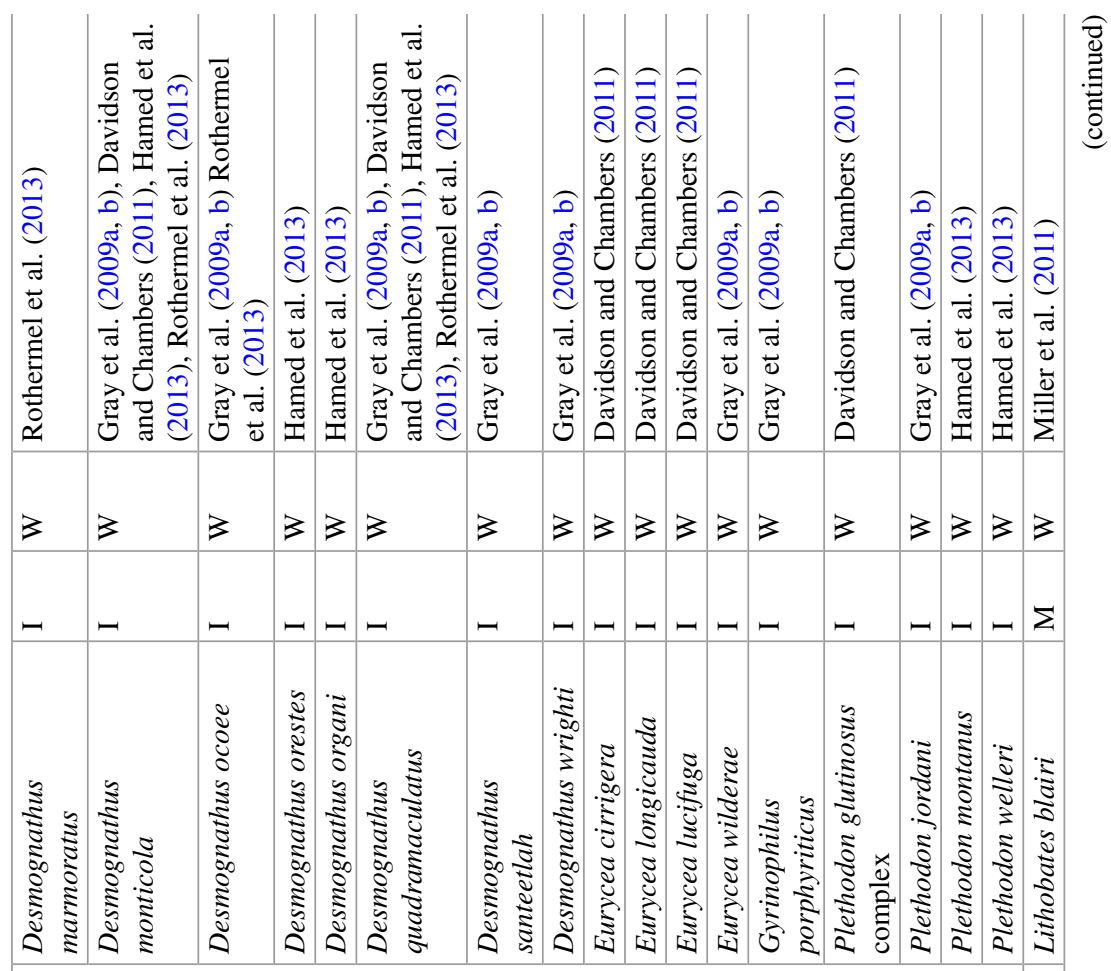

高

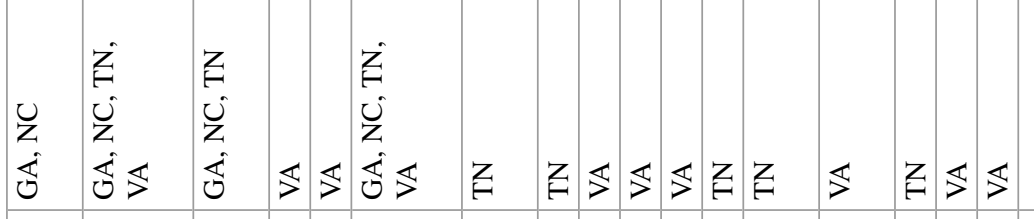




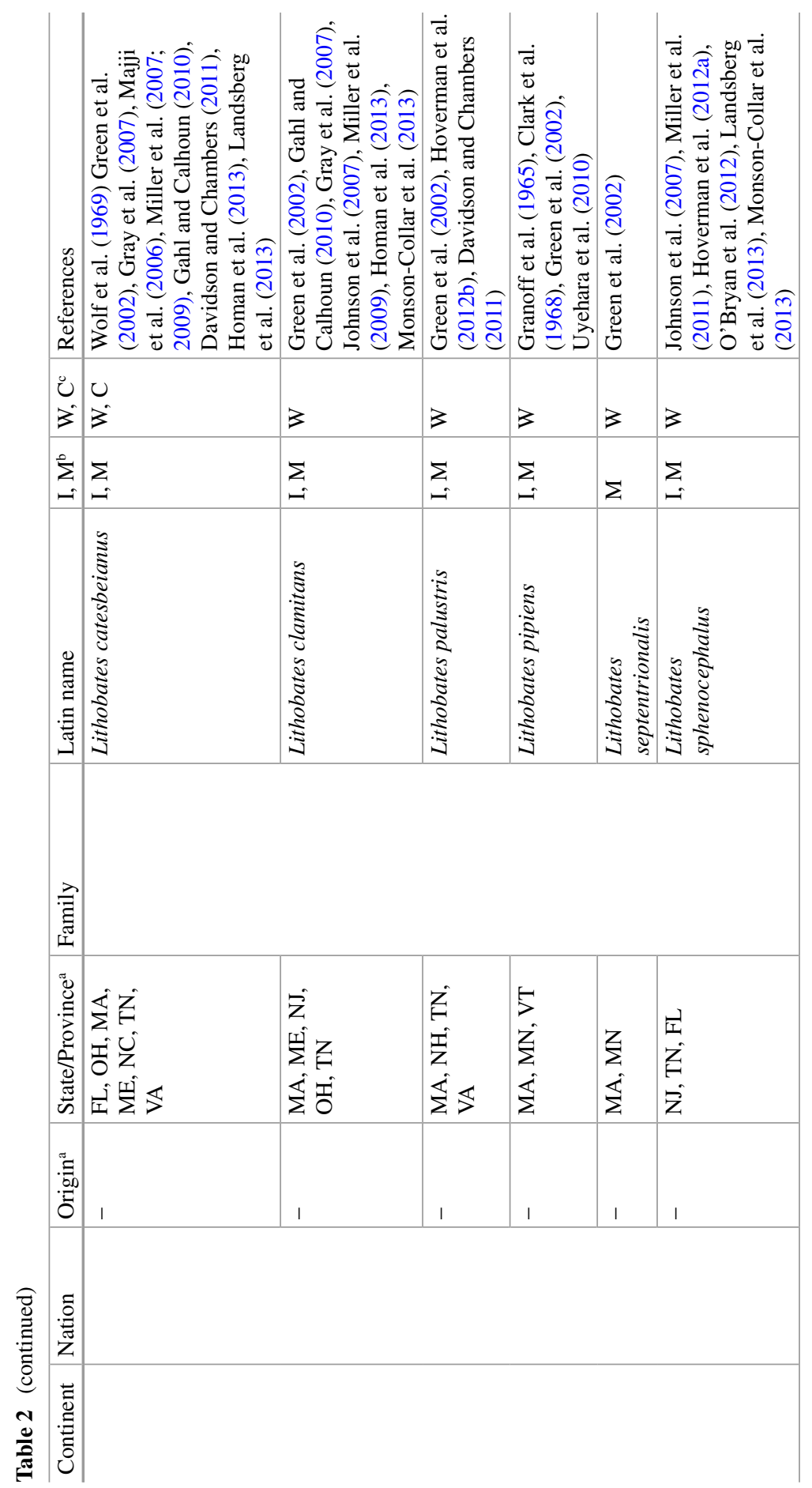




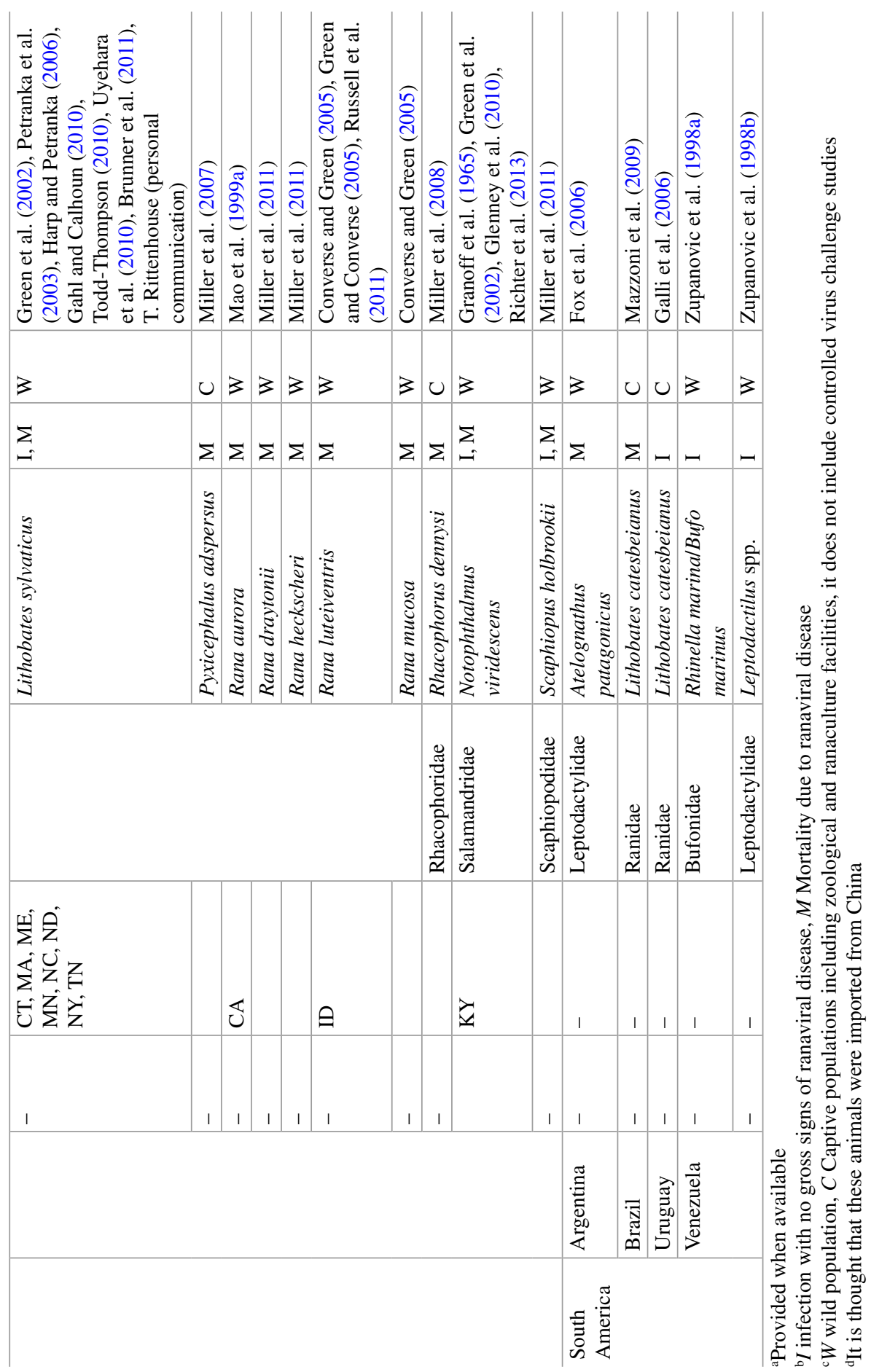




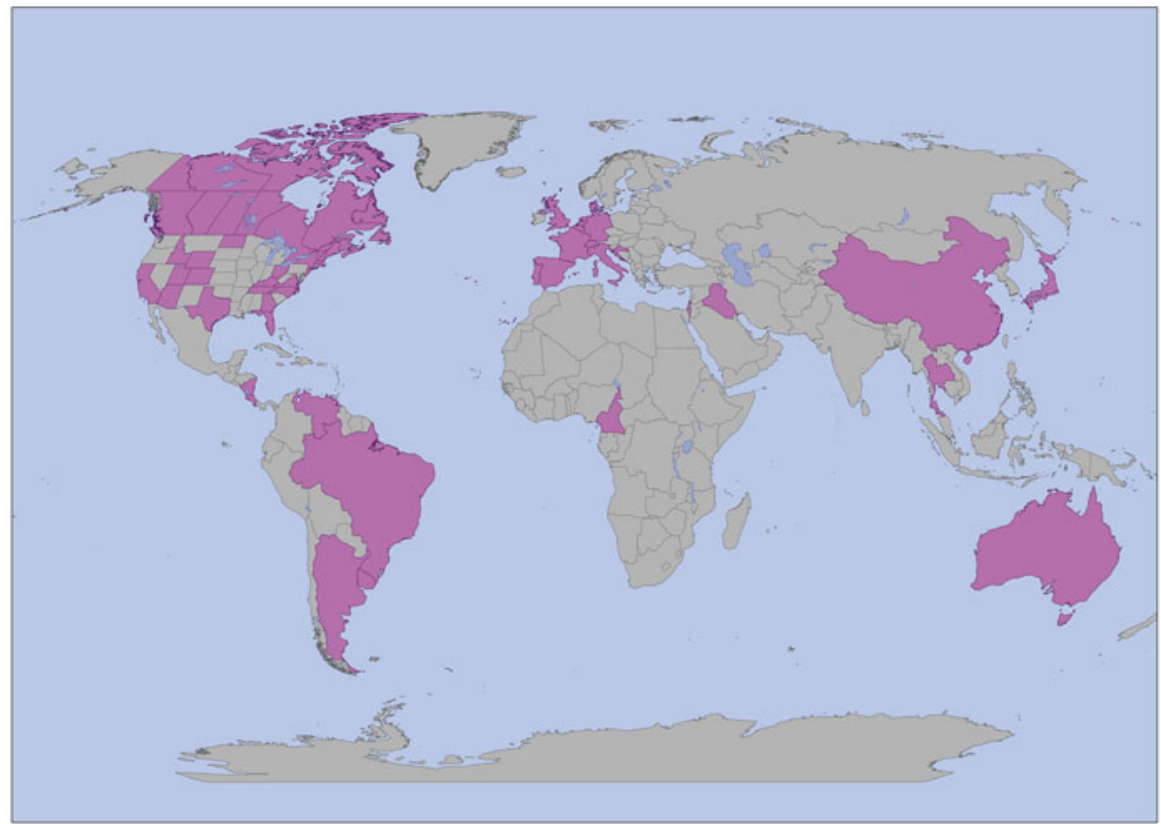

Fig. 3 Distribution of ranavirus cases involving amphibians

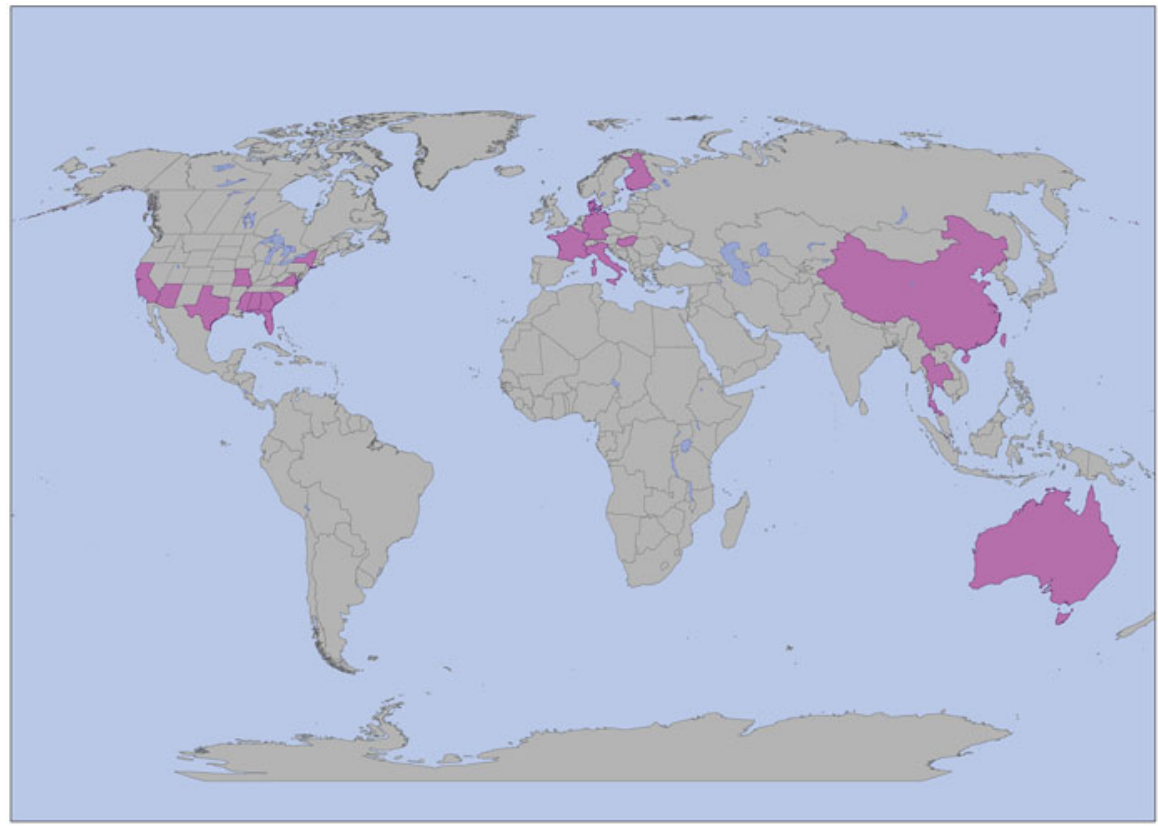

Fig. 4 Distribution of ranavirus cases involving fish 


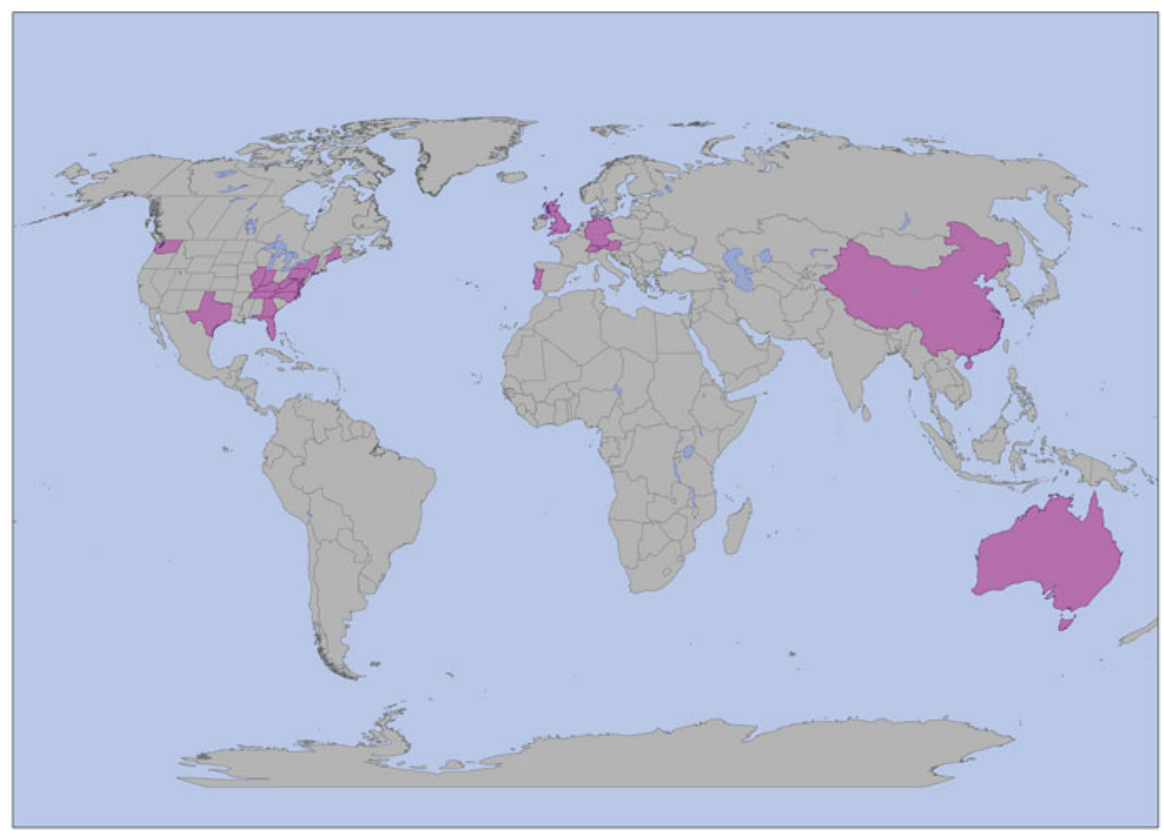

Fig. 5 Distribution of ranavirus cases involving reptiles

of ranavirus infection are not always apparent and can be confused with other factors, and mortality events are not easily observed due to their rapid progression and the fast decomposition of dead hosts (Brunner et al. 2015; Miller et al. 2015). It is perhaps not surprising that caecilians, which are fossorial and as a group poorly studied, are the only amphibian family with no reports of ranavirus infection. To our knowledge, no one has tested the susceptibility of caecilians to ranavirus or performed surveillance in wild populations.

There are three recognized species of ranaviruses that are known to infect amphibians: FV3, ATV, and BIV. Also, there are several other ranaviruses that have been isolated from amphibians (e.g., common midwife toad virus, CMTV; Balseiro et al. 2009), but are not currently recognized as ranavirus species. As discussed in Jancovich et al. (2015), declaring a given isolate as a unique viral species is complex, and compounded by the fact that there is considerable sequence conservation, often greater than $95 \%$ at the amino acid level among many ranavirus isolates. A challenge for the future is identifying genetic sequences that allow for unique characterization of ranaviruses in an evolutionary context. Below, we discuss what is known about some of the ranaviruses that infect amphibians.

\subsection{Frog Virus 3}

Since its initial isolation from the leopard frog, cases of FV3 and FV3-like infections and disease have been confirmed in a growing number of amphibian species (as well as fish and reptiles, Sects. 3 and 4). Infected animals include some that were 
visibly diseased or dying, and several cases from apparently healthy individuals. Outbreaks of FV3 and FV3-like viruses in amphibians have occurred across large sections of North America and have been found in many different species of anurans and urodeles in eastern North America. In both the USA and Canada, the number of infections caused by FV3 or FV3-like viruses is unknown, because many researchers do not report the strain of ranavirus detected in their studies. There have been no reports of ranavirus infections in Mexico, likely due to a lack of investigation. In Central America, an FV3-like ranavirus has been detected in a minimum of ten amphibian species. Specifically, in Costa Rica, at least eight species are known to have been infected with an FV3-like ranavirus (Whitfield et al. 2013), and in Nicaragua, an FV3-like ranavirus has been detected in at least two species (Stark et al. 2014). Cases of FV3 infection and disease in South America have been primarily associated with American bullfrog (L. catesbeianus) farms (Mazzoni et al. 2009), but a single case of infection in a wild amphibian population of Patagonia frogs (Atelognathus patagonicus) was reported (Fox et al. 2006).

In Europe, the first outbreaks of FV3-like viruses occurred in the southeastern UK in common frogs (Cunningham et al. 1993, 1996; Drury et al. 1995). The emergence of these viruses in common frogs was followed quickly by their emergence in common toads (Bufo bufo; Hyatt et al. 2000; Cunningham et al. 2007). Since then, FV3-like infections have been documented in common newts (Lissotriton vulgaris) and common midwife toads (Alytes obstetricans; Duffus et al. 2014). FV3-like viruses have also been detected in amphibians in continental Europe (e.g., Ariel et al. 2009; Stöhr et al. 2013c). In total, FV3-like ranaviruses have been documented in a minimum of five amphibian species in Europe.

In Asia, there have been several reports of FV3-like viruses in both wild and captive populations of amphibians. In China, an FV3-like virus was found across Heilongjiang Province in $5.7 \%$ of adult and $42.5 \%$ of larval $R$. dybowskii surveyed (Xu et al. 2010). In Japan, an FV3-like ranavirus was responsible for a mass mortality of American bullfrog tadpoles, an introduced species (Une et al. 2009a). In this case, adult bullfrogs and fish (Gnathopogon spp.) that were present in the pond did not die or appear moribund, but ranavirus was documented in the livers of the fish (Une et al. 2009b), suggesting interclass transmission. The single case of ranavirus infection in Africa reported by Docherty-Bone et al. (2013) is also likely to be an FV3-like virus. The primers used were those developed for the major capsid protein of FV3, but the PCR products were of poor quality and could not be sequenced (Docherty-Bone et al. 2013). In general, surveillance data for ranaviruses in Asia and Africa have been slower to accumulate than for North America or Europe, which are essential to understanding the distribution, host range, and threat of ranaviruses.

As mentioned, FV3 and FV3-like ranaviruses have affected many aquaculture facilities. In Japan, a ranavirus with $99 \%$ homology to the major capsid protein of FV3 was isolated from a mass mortality event in cultured Japanese clouded salamanders (Hynobius nebulosus, Une et al. 2009a). In the Americas, FV3-like viruses have also been documented in association with mass mortality events in aquaculture facilities. In the USA, FV3-like viruses have been responsible for mass mortalities 
of tadpoles and recently metamorphosed American bullfrogs in culture facilities (Majji et al. 2006; Miller et al. 2007). In Brazil, FV3-like ranaviruses have been responsible for mass mortality events at several aquaculture facilities that rear American bullfrogs (Mazzoni et al. 2009). There is some evidence that suggests that the FV3-like viruses that are present in aquaculture facilities are more virulent than those found in natural populations (Majji et al. 2006; Hoverman et al. 2010, 2011).

\subsection{Ambystoma Tigrinum Virus}

Ambystoma tigrinum virus was first described in larval Sonora tiger salamanders (Ambystoma tigrinum stebbinsi) collected from the San Rafael Valley in Arizona, USA in 1995 (Jancovich et al. 1997). This virus was isolated from a population that had both apparently healthy and visibly diseased salamander larvae (Jancovich et al. 1997). The virus that was later isolated was successfully transmitted to healthy individuals via the water, as well as through the feeding of body parts of infected animals to healthy individuals in the laboratory (Jancovich et al. 1997). After fulfilling Koch's Postulates, it was determined that ATV was the causative agent of the disease found in the tiger salamander larvae and the likely cause of recurrent epizootics first described in 1985 (Collins et al. 1988).

Ambystoma tigrinum virus in the wild appears to be restricted to western North America (Jancovich et al. 2005; Ridenhour and Storfer 2008). Phylogeographic studies of ATV strains suggest local range expansion and long-distance colonization events, which may be attributed to anthropogenic spread (Jancovich et al. 2005). ATV is found in tiger salamander larvae sold commercially as fish bait (Picco and Collins 2008), providing an anthropogenic explanation for range expansion.

Because of the potential for introduction, ATV may be a threat to naïve urodeles of conservation concern. In the lab, the endangered California tiger salamander (Ambystoma californiense) is susceptible to ATV and experienced mortality associated with infection (Picco et al. 2007). There have been no reports of ATV infections or associated mortality in wild California tiger salamanders, probably due in part to the ban on importation of non-native Ambystomatidae into the state.

Patterns of ATV infection are more similar among ponds in the same year, rather than between years (Greer et al. 2009). In natural populations of tiger salamanders located on the Kaibab Plateau in the Northern Kaibab National Forest in Arizona, outbreaks of ATV appear to be synchronous (Greer et al. 2009). Interestingly, despite four years of observation, no visible signs of disease were seen, even in cases where the infection rate in the pond was greater than $50 \%$ (Greer et al. 2009). It is thought that the lack of observed morbidity and mortality in these populations is due to coevolution between ATV and the host (Greer et al. 2009). This may be the case as there is evidence of local adaptation in ATV strains isolated from the western USA (Ridenhour and Storfer 2008). 


\subsection{Bohle Iridovirus}

Bohle iridovirus was first described in the early 1990s and was isolated from recently metamorphosed ornate burrowing frogs (Limnodynastes ornatus) in Australia that had been raised in captivity and suddenly died (Speare and Smith 1992). Using sequences from the major capsid protein, BIV was determined to be most closely related to Epizootic hematopoietic necrosis virus (EHNV), a fish ranavirus that had also been isolated in Australia (Hyatt et al. 2000). Subsequent experimentation showed that BIV was pathogenic in additional species of Australian anurans and was involved in mortality events in captive and wild settings (Cullen et al. 1995; Cullen and Owens 2002).

Until recently, BIV and BIV-like viruses were known only from Australian anurans. Then, in 2010, a BIV-like virus was isolated from boreal toads (Anaxyrus boreas boreas) held in an Iowa, USA aquarium that experienced a mass mortality. The virus, tentatively designated Zoo Ranavirus (ZRV), was found to have high sequence homology with BIV (Cheng et al. 2014). These toads had been housed with multiple species, some of which were collected in the wild from Southeast Asia, suggesting a potential route of introduction. Other species that were infected with ZRV but did not experience mortality in the outbreak included a Malayan horned frog (Megophrys nasuta) and a bumblebee toad (Melanophryniscus stelzneri, Cheng et al. 2014). At present, it is unknown whether ZRV represents a novel North American isolate of BIV, or the transmission of BIV from another captive animal.

\subsection{Other Amphibian Ranaviruses}

Common midwife toad virus (CMTV) was first isolated from common midwife toad tadpoles experiencing a mass mortality event in 2007 in northern Spain (Balseiro et al. 2009). A second mass mortality event during 2008 in the same region of Spain involving CMTV affected common midwife toad tadpoles and juvenile alpine newts (Mesotriton alpestris; Balseiro et al. 2010). A long-term study in Spain reported six amphibian species experiencing die-offs due to CMTV at several sites, with population declines documented in three species (Price et al. 2014). CMTV infections have also been found in invasive populations of American bullfrogs in Belgium (Sharifian-Fard et al. 2011), and in both captive and wild animals in the Netherlands (Kik et al. 2011, 2012). CMTV appears to be the most common ranavirus in continental Europe, but has not been found elsewhere. This virus appears to be evolutionarily unique from other ranaviruses (Mavian et al. 2012); thus, species designation may be warranted.

Another possibly unique ranavirus was isolated recently from the endangered Chinese giant salamander (Andrias davidianus; Geng et al. 2011; Chen et al. 2013; Ma et al. 2014). The virus was isolated from captive populations, and in all cases resulted in high morbidity and mortality (Geng et al. 2011; Chen et al. 2013; 
Ma et al. 2014). Phylogenetic analyses have shown that it is most closely related to CMTV (Chen et al. 2013). Dr. Lingbing Zeng has been working with several Chinese giant salamander farms, and has documented the virus across 11 Chinese provinces (L. Zeng and J. Ma, Yangtze River Fisheries Institute, unpublished data). The emergence of this ranavirus in China is a serious conservation threat (Cunningham et al. 2015).

There are several other ranaviruses that have been isolated from amphibians and named, but are not considered unique species. Rana grylio virus (RGV) was isolated in the mid-1990s in China (Zhang et al. 1996), and appears to be closely related to FV3 (Lei et al. 2012). The tiger frog virus (TFV) was isolated in 2000 from Chinese amphibians involved in a mass mortality event at a ranaculture facility (Weng et al. 2002). Both of these ranaviruses may be a threat to aquaculture facilities in Asia.

\section{Ranaviruses Infecting Fish}

Ranaviruses can cause severe systemic diseases in finfish in both marine and freshwater environments (Whittington et al. 2010). EHNV was the first ranavirus associated with fish die-offs, and was isolated in 1985 in Australia (Langdon et al. 1986b). A genetically distinct, but closely related ranavirus, European catfish virus (ECV), was detected soon after in Europe (Ahne et al. 1989). The Santee-Cooper ranavirus (SCRV), known informally as largemouth bass virus (LMBV) and currently classified by the International Committee on the Taxonomy of Viruses (ICTV) as a ranavirus, was associated with wild fish epizootics in the USA (Plumb et al. 1996). Although typically associated with morbidity in amphibians and reptiles, FV3 also has been isolated from a moribund threespine stickleback (Gasterosteus aculeatus) during a sympatric epizootic in the northern red-legged frog (Rana aurora; Mao et al. 1999a). There are three species of ranavirus recognized by the ICTV that primarily infect fish: EHNV is not known to occur naturally in any country except Australia; ECV appears to be confined to Europe; and SCRV has primarily been detected in North American fishes.

While both EHNV and ECV have impacted aquaculture (Whittington et al. 2010), BIV appears to be restricted to a single outbreak in hatchery-reared Nile tilapia fry (Oreochromis niloticus) in Australia (Ariel and Owens 1997). Recently, SCRV and FV3 have been repeatedly detected among hatchery-reared freshwater fishes in North America and Asia (Woodland et al. 2002b; Prasankok et al. 2005; Deng et al. 2011; George et al. 2014; Chinchar and Waltzek 2014; Waltzek et al. 2014). Two genetically distinct but related ranaviruses, Singapore grouper iridovirus (SGIV) and grouper iridovirus (GIV), have negatively impacted grouper mariculture in Asia since the 1990s (Chua et al. 1994; Murali et al. 2002; Qin et al. 2003). The reasons for the emergence of ranaviruses as pathogens of finfish within both natural and managed populations are unknown. However, the repeated detection of the same finfish ranaviruses (e.g., SCRV) around the globe suggests that the international movement of live 
animals and their products likely plays an important role in the occurrence of these epizootics (Hedrick and McDowell 1995; Plumb and Zilberg 1999a; Grant et al. 2005; Schramm and Davis 2006; Deng et al. 2011; George et al. 2014).

\subsection{Epizootic Haematopoietic Necrosis Virus}

The first ranavirus to be associated with systemic infection and mass mortality in any vertebrate species was EHNV. It was identified as the cause of epizootic mortality of redfin perch (Perca fluviatilis) and rainbow trout (Oncorhynchus mykiss) in Australia in 1985 (Langdon et al. 1986b, 1988; Langdon and Humphrey 1987). The source of the outbreak was not determined. A survey to detect viral infections of salmonids conducted in Australia between 1981 and 1984 did not identify any viruses (Langdon et al. 1986a), so EHNV may not have been present in trout prior to these first mortality events. Although redfin perch populations were not surveyed, there was no record of prior mass mortality (Whittington et al. 1996). To date, there have been no other known cases of EHNV mortality in the wild other than redfin perch, despite the fact that at least 14 additional species are known to be susceptible to this ranavirus according to experimental challenges (Whittington et al. 2010; Becker et al. 2013). Perhaps the difficulty of observing free-living finfish species combined with unreliable reporting of clinical disease is responsible for the current lack of EHNV detection in Australia.

The impact of EHNV on aquaculture has been limited to farmed rainbow trout in southeastern Australia; salmonid populations of Tasmania and western Australia remain free of EHNV infection. EHNV infection is endemic in wild redfin perch populations throughout southeastern Australia, excluding Tasmania. Redfin perch are highly susceptible to EHNV, while rainbow trout are relatively resistant (Whittington and Reddacliff 1995). In affected trout farms, EHNV tends to occur in only a small proportion of fish (Whittington et al. 1994, 1999), with total mortality generally $\leq 4 \%$ across all age classes. While few fish become infected, the mortality rate of infected individuals appears to be high (Whittington et al. 1994, 1999). In contrast, EHNV causes severe disease in redfin perch, affecting high proportions of populations of fingerlings and juveniles in endemic areas, and also naïve adults that enter new areas (Langdon et al. 1986b; Langdon and Humphrey 1987; Whittington et al. 1996). Anecdotal evidence suggests that redfin perch populations exposed to EHNV can recover over a few years. There is some evidence based on virus isolation and serology that both redfin perch and rainbow trout are capable of living with subclinical infections of EHNV, thus possibly function as reservoirs for the pathogen (Whittington et al. 2010).

In redfin perch, there has been progressive spread of EHNV into river systems, possibly due to natural fish migration, fish releases, and avifauna (Whittington et al. 1996). Waterborne infection and ingestion of infected fish are transmission routes of EHNV between susceptible hosts within a population, but longer distance spread is likely a result of human activity, particularly by movement of infected trout 
fingerlings in aquaculture (Langdon et al. 1988; Whittington et al. 1994, 1999). Annual outbreaks on trout farms may be due to persistence of the virus in the local environment or reinfection from wild redfin perch.

Natural epizootics in redfin perch occur most often in summer, and there is evidence of a positive relationship between EHNV pathogenicity and water temperature. Redfin perch are not susceptible to EHNV below $10^{\circ} \mathrm{C}$, and incubation periods for the virus are shorter at higher temperatures (Whittington and Reddacliff 1995). In rainbow trout, EHNV outbreaks have occurred between 11 and $20^{\circ} \mathrm{C}$ (Whittington and Reddacliff 1995; Whittington et al. 1994, 1999). Temperature-dependent pathogenicity may be related to viral replication rates (Ariel et al. 2009).

The first transmission studies with EHNV were conducted by Langdon (1989) who identified a wide range of susceptible hosts, a factor that contributed to the listing of EHNV by the International Office of Epizootics (OIE). Although there are recognized deficiencies in laboratory challenge models to determine the susceptibility of host fish to virus isolates under natural conditions, a potential increase in the host range of EHNV infections has been predicted. In three separate challenge studies, black bullhead (Ameiurus melas), pike (Esox Lucius), and pike-perch (Sander lucioperca) experienced significant mortality following bath exposure to EHNV (Bang-Jensen et al. 2009, 2011a; Gobbo et al. 2010). On the other hand, goldfish (Carassius auratus), common carp (Cyprinus carpio), and European sheatfish (Silurus glanis) did not experience significant mortality following bath exposure to EHNV (Bang-Jensen et al. 2011b; Leimbach et al. 2014). Like other ranaviruses, the outcome of EHNV infection may depend on various viral, host, and environmental factors including: virus concentration and route of delivery, viral strain, host genetics, host density and age, and water temperature (Brunner et al. 2015). For example, lower mortality was observed when European redfin perch stocks were challenged with EHNV, but it was these individuals that caused transmission of the pathogen to and extensive mortality in Australian redfin perch that were cohoused with them (Ariel and Bang-Jensen 2009).

\subsection{European Catfish Virus}

European catfish virus is the most important ranavirus that causes disease of fish in Europe. It was referred to as European sheatfish virus (ESV) prior to its formal classification. This pathogen has triggered epizootics in cultivated sheatfish in Germany (Ahne et al. 1989, 1991) and wild black bullheads in France and Italy (Pozet et al. 1992; Bovo et al. 1993; Bigarré et al. 2008). Evidently, the virus is endemic in some locations (e.g., Lake le Bourget and Lake Apremont in France; Bigarré et al. 2008). In Italy, the disease occurs in both farmed and wild black bullhead and in farmed brown bullhead (A. nebulosus), and affects production of these species (Ariel et al. 2010). An ECV outbreak was detected in brown bullheads in Hungary in 2008 (Juhász et al. 2013). 
The host range, geographic distribution, and diversity of ECV strains in Europe is incompletely understood. The virus is readily transmitted to catfish via a range of challenge methods including bath exposure, cohabitation, and intramuscular injection (Ahne et al. 1990; Pozet et al. 1992), and results in only a small proportion of exposed catfish surviving (Pozet et al. 1992). Interestingly, Gobbo et al. (2010) found different patterns of susceptibility based on closely related ranavirus strains, as black bullheads were susceptible to ECV, but not to the ESV isolate used in this study. More recent experiments have demonstrated variable pathogenicity of different isolates of ECV, and a strong impact of water temperature on disease outcome, with mortality varying between 8 and $10 \%$ among challenged sheatfish (Leimbach et al. 2014). In three separate experimental challenge studies, black bullhead, pike, and sheatfish experienced significant mortality following bath exposure to strains of ECV (Bang-Jensen et al. 2009; Gobbo et al. 2010; Leimbach et al. 2014). Goldfish, common carp, and pike-perch did not experience significant mortality following bath exposure to ECV strains (Bang-Jensen et al. 2011a, b).

\subsection{Santee-Cooper Ranavirus}

The discovery of an iridovirus from largemouth bass (Micropterus salmoides) was reported from a 1995 epizootic that occurred in the Santee-Cooper Reservoir, South Carolina, USA (Plumb et al. 1996). Accordingly, the authors named the pathogen LMBV based on the host. Subsequent genetic analyses confirmed LMBV to be a unique member of the genus Ranavirus (Mao et al. 1997, 1999b), and nearly identical to doctor fish virus (DFV) and guppy virus 6 (GV6), which had previously been isolated from imported ornamental fishes originating in Southeast Asia (Hedrick and McDowell 1995). The designation of LMBV later as SCRV was based on the location where the virus was isolated. However, Grizzle et al. (2002) disputed the change in name citing the fact that the LMBV had previously (1991) been isolated in largemouth bass from Lake Weir, Florida, USA (Francis-Floyd 1992). The aforementioned studies and more recent phylogenetic analyses support LMBV, GV6, and DFV as strains of the same species that is formally known by the ICTV as the SCRV (Holopainen et al. 2009). Importantly, it has been argued based on the genetic sequence analyses as well as epidemiological and pathobiological characteristics that SCRV may be too divergent to be included within the genus Ranavirus (Hyatt et al. 2000; Whittington et al. 2010; Jancovich et al. 2015).

Epizootics attributable to SCRV have been repeatedly reported among wild populations of North American largemouth bass (Grizzle and Brunner 2003; Plumb and Hanson 2011). Although SCRV virulence appears variable in natural and experimental settings, typical outbreaks involve adult fish observed during summer at the surface with buoyancy or equilibrium problems. In general, the factors responsible for SCRV epizootics remain unknown, and may be case-specific. However, genetic background of the largemouth bass population, SCRV exposure history within that population, SCRV strain, and environmental factors (e.g., low dissolved oxygen 
associated with warmer water temperatures) have been argued as potential factors contributing to emergence (Grizzle and Brunner 2003; Plumb and Hanson 2011). Experimental infections of SCRV in largemouth bass and striped bass (Morone saxatilis) revealed a direct correlation between virus titer and mortality by both injection and immersion; however, striped bass experienced lower overall cumulative mortality (Plumb and Zilberg 1999b; Zilberg et al. 2000). Experimental transmission of SCRV in largemouth bass via oral administration resulted in infection of the skin and internal organs (e.g., swim bladder) without mortality (Woodland et al. 2002a).

In the USA, SCRV has also been isolated from a wide range of wild asymptomatic freshwater fishes ( 6 families and 17 species) in 31 states ranging as far south as Florida to as far west as Arizona, and to the northern states of Wisconsin, Michigan, New York, Vermont, and Delaware (Goldberg 2002; Woodland et al. 2002b; Groocock et al. 2008; USFWS 2011; Iwanowicz et al. 2013; Table 3). Most recently, a SCRV strain was isolated from the exotic Northern snakehead (Channa argus) recently introduced into the Chesapeake Bay watershed (Iwanowicz et al. 2013). Asian strains of SCRV (DFV/GV6) were shown experimentally to infect and induce low mortality in rainbow trout and chinook salmon (Oncorhynchus tshawytscha), but not channel catfish (Ictalurus punctatus; Hedrick and McDowell 1995). A SCRV strain isolated from moribund hatchery-reared largemouth bass reared in China was found to be highly lethal to largemouth bass (Deng et al. 2011); however, little or no mortality was observed in seven other species tested including koi (Cyprinus carpio; Table 3). In contrast, a recent mass mortality event among farmed koi in southern India was attributed to a strain of SCRV (George et al. 2014), although the authors did not provide a detailed description of viral-induced pathology.

It seems likely that SCRV has been disseminated across the USA and globally through the unrestricted movement of live fish and their products associated with the ornamental (Hedrick and McDowell 1995; Deng et al. 2011; George et al. 2014), food (Plumb and Zilberg 1999a), and angling industries (Grant et al. 2005; Schramm and Davis 2006). For example, in the USA, largemouth bass angling tournaments may contribute to the spread of SCRV to naïve fish by placing infected and uninfected fish in close proximity; however, the stress associated with angling has not been shown to greatly increase SCRV-associated mortality (Grant et al. 2005; Schramm and Davis 2006). Given that SCRV remains infectious in frozen tissues, the import/export of frozen fish tissues may represent another mechanism by which the virus can be spread (Plumb and Zilberg 1999a). Future concerted surveillance efforts are needed to confirm the risk that the aforementioned industries play in the global dissemination of SCRV.

\subsection{Frog Virus 3}

Although only a single case of FV3 infection has been reported in wild fish (Mao et al. 1999a), a number of cases of piscine infection with FV3 have been reported among captive/cultured fish. In the former, an FV3-like virus was recovered from a 


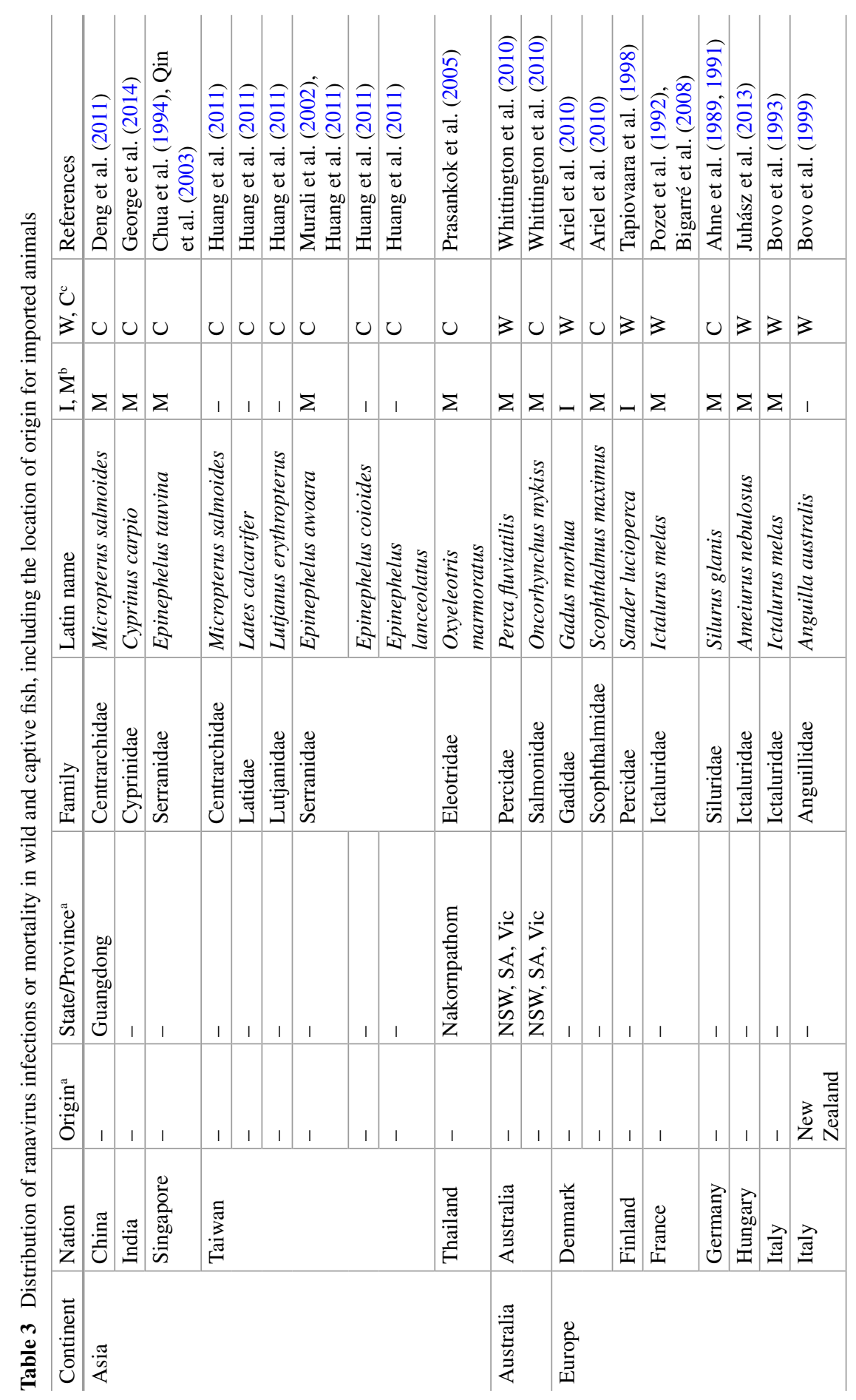




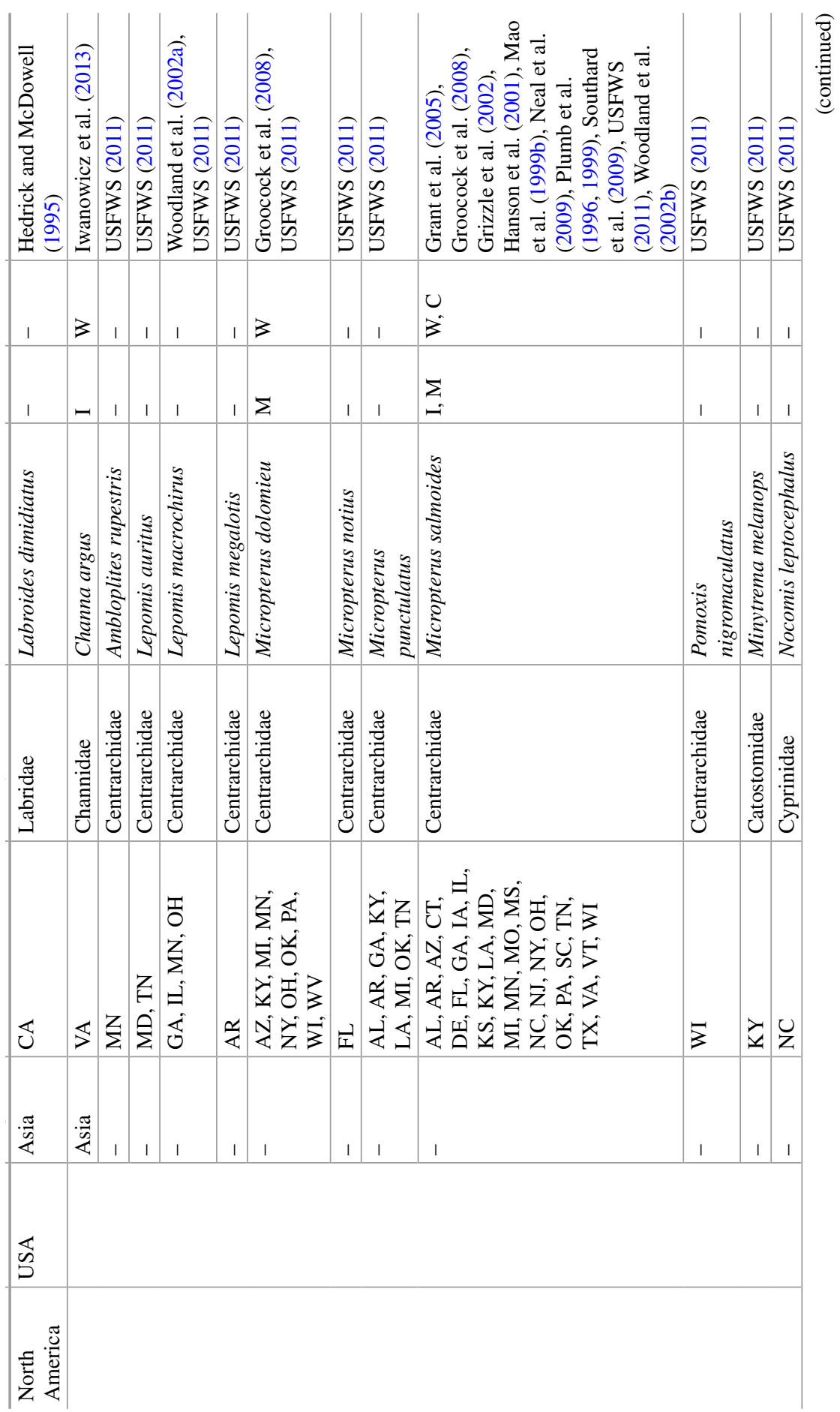




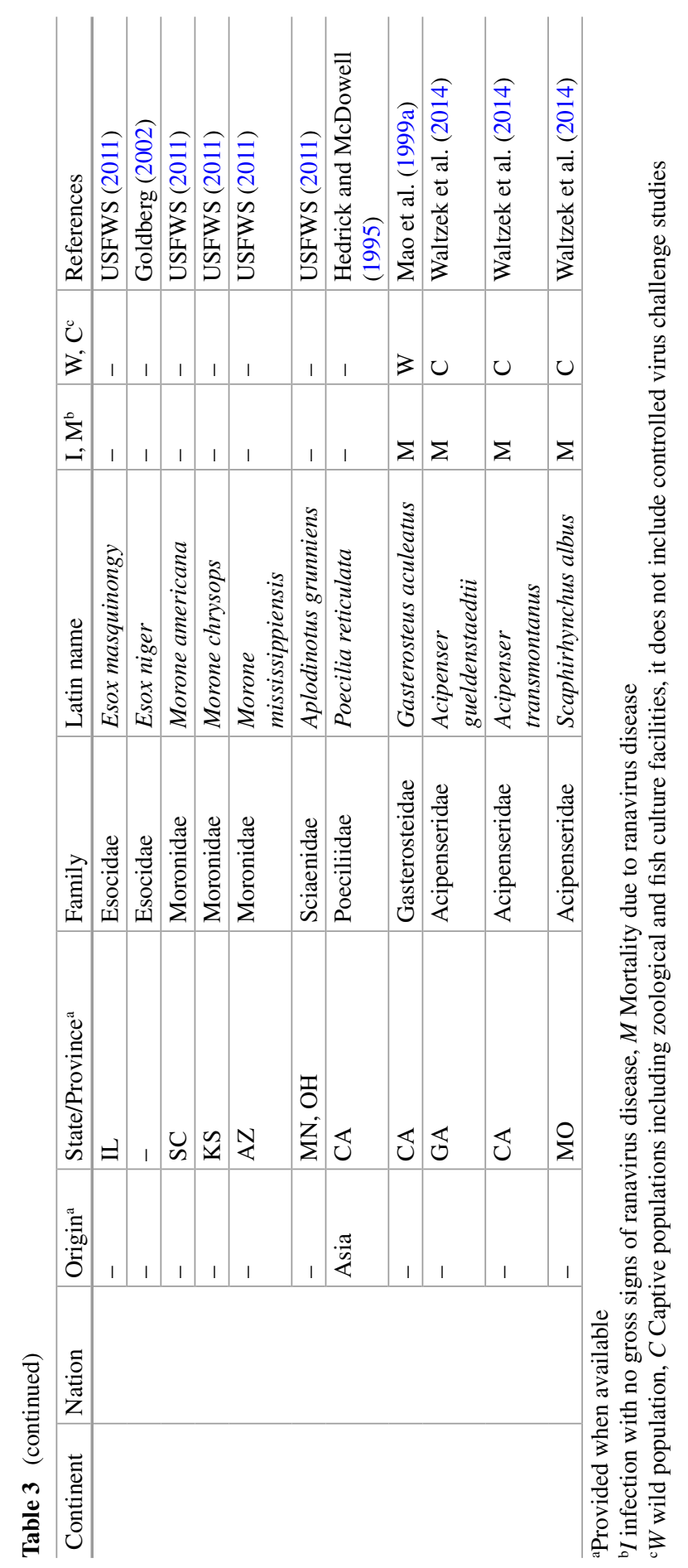


single moribund threespine stickleback that was coinfected with myxozoan parasites, obscuring the role of the virus in the disease (Mao et al. 1999a). However, FV3-like ranaviruses have been isolated from captive fishes on several occasions. A ranavirus displaying $98-99 \%$ nucleotide identity to FV3 over a portion of the major capsid gene has been reported among cultured marbled sleeper goby (Oxyeleotris marmoratus) in Thailand (Prasankok et al. 2005). Furthermore, FV3 outbreaks have impeded efforts to restore populations of the critically endangered pallid sturgeon (Scaphirhynchus albus) in the Missouri River Basin of the USA (Waltzek et al. 2014). High-mortality epizootics were reported among young-of-the-year pallid sturgeon in 2001, 2009, and 2013 at the Blind Pony Hatchery in Sweet Springs, Missouri, USA (Chinchar and Waltzek 2014; Waltzek et al. 2014). Experimental transmission of the 2009 isolate recreated the same high-mortality disease in naïve juvenile pallid sturgeon following bath exposure (Waltzek et al. 2014). Furthermore, an FV3 strain isolated from moribund hatchery-reared Russian sturgeon (Acipenser gueldenstaedtii) was found to be lethal to both Russian and lake (A. fluvescens) sturgeon following intraperitoneal injection (Waltzek et al. 2014). Finally, an FV3-like ranavirus was isolated from juvenile white sturgeon (A. transmontanus) on a California, USA, farm during an unusual mortality event in 1998 (Waltzek et al. 2014).

Experimental transmission studies using FV3-like viruses isolated from a diversity of ectothermic vertebrate classes have been shown to infect black bullhead (Ameiurus melas), northern pike, pike-perch, mosquito fish (Gambusia affinis), and bluegill (Lepomis macrochirus), although little or no mortality was observed in these species (Gobbo et al. 2010; Bang-Jensen et al. 2009, 2011a, b; Brenes et al. 2014a). Similarly, recent North American fish health surveys resulted in the isolation of FV3 from healthy appearing fathead minnow (Pimephales promelas), walleye (Sander vitreus), and northern pike (Waltzek et al. 2014). Although preliminary, these data suggest that imperiled sturgeon may be predisposed to infections with FV3-like viruses; whereas, other fishes may simply act as viral carriers or dead-end hosts. Future studies are needed to explore the importance of FV3-like viruses across a wider range of wild and captive fish species as well as the potential role of aquaculture in the global dissemination of these important pathogens.

\subsection{Bohle Iridovirus}

As indicated above, BIV was first isolated from diseased ornate burrowing frog tadpoles (Limnodynastes ornatus) in Australia. Although designated as a distinct species by the ICTV, the sequence of the MCP gene is $97.8 \%$ identical to that of EHNV, which is endemic in a different part of the continent (Marsh et al. 2002). As with FV3, laboratory challenge studies demonstrated that BIV is also pathogenic to fish, in this case to barramundi (Lates calcarifer), a popular sport fish in Australia (Moody and Owens 1994). On just one occasion, BIV may have been associated with high mortality in hatchery-reared Nile tilapia fry in Australia (Ariel and Owens 1997). Although the authors did not genetically characterize the iridovirus, feeding 
the moribund tilapia fry to barramundi fingerlings reproduced disease similar to what had been reported following challenge studies of barramundi to BIV (Moody and Owens 1994).

\subsection{Taxonomically Unassigned Ranaviruses That Affect Fish}

Although ranaviruses infecting freshwater fishes are relatively well characterized, less is known about the significance of ranaviruses infecting cultured or feral populations of marine fishes. Exceptions include two related ranaviruses, SGIV and GIV, which significantly impact grouper mariculture in Asia (Chua et al. 1994; Murali et al. 2002; Qin et al. 2003). Phylogenetic analysis based on the 26 conserved iridovirus genes demonstrated that GIV and SGIV are each other's closest relatives; however, these viruses are genetically divergent from other ranaviruses (Eaton et al. 2007). Therefore, GIV/SGIV may need to be considered as a new genus within the family Iridoviridae (Jancovich et al. 2015).

SGIV was first identified following a mass mortality event of net-cage farmed brown-spotted grouper (Epinephelus tauvina) in Singapore in 1994 (Chua et al. 1994). The authors referred to the epizootic as Sleepy Grouper Disease; however, they failed to isolate or genetically characterize the virus. In 1998, the same disease was again observed in Singapore farms following imports of brown-spotted grouper fry from Taiwan (Qin et al. 2003). These authors genetically characterized the virus as a novel ranavirus, and named it SGIV (Qin et al. 2003). Similarly, GIV has negatively impacted production of yellow grouper (Epinephelus awoara) in Taiwan (Murali et al. 2002). Delivery of the virus to yellow grouper by injection resulted in $100 \%$ mortality during experimental challenges (Murali et al. 2002). A recent study reported the isolation of SGIV and GIV strains from grouper and non-grouper species cultured in Taiwan (Huang et al. 2011, Table 3). This study illustrates the apparent expanding host range of SGIV/GIV including the first isolation of these viruses in freshwater (largemouth bass) and catadromous (barramundi) fishes.

Other partially characterized ranaviruses from wild marine fishes include cod ranavirus (CoIV) isolated from Danish Atlantic cod (Gadus morhua; Ariel et al. 2010) and the short-finned eel ranavirus (SERV) isolated from short-finned eel (Anguilla australis) off the coast of New Zealand (Bang-Jensen et al. 2009). Ranaviruses isolated from seemingly healthy cultivated freshwater and marine fishes include the pike-perch iridovirus (PPIV) isolated from Finnish pike-perch fingerlings (Tapiovaara et al. 1998) and Ranavirus maxima (Rmax) isolated from Danish turbot (Scophthalmus maximus) fry (Ariel et al. 2010). Preliminary phylogenetic analyses of these fish viruses have revealed they represent previously unknown ranaviruses, warranting more comprehensive study into their biology and potential impact on cultivated and wild populations (Holopainen et al. 2009; Jancovich et al. 2015). 


\section{Ranaviruses Infecting Reptiles}

Although ranaviral disease has been described in reptiles in a number of cases, it is likely that these disease events are underreported (Daszak et al. 1999; Johnson et al. 2010; Allender 2012) due to lack of awareness, few long-term research studies, and lack of disease monitoring in biological studies. It is notable that reports of ranavirus infections in reptiles have markedly accelerated over the past decade. The rising awareness of these viruses in chelonians as important infectious agents may have contributed to the high number of case reports in these species as well as increasing the awareness of these viruses as pathogens in reptiles in general (Shaver 2012). It has also been surmised that the global trade of reptiles and amphibians in combination with the wide host range of ranaviruses is contributing to its emergence (Stöhr et al. 2013a). This is of significant importance for wild and captive reptiles as well as amphibians and fish.

There is an increasing amount of information available on ranaviruses capable of infecting reptiles. The majority of ranaviruses detected in reptiles so far have been FV3-like (Huang et al. 2009; Allender et al. 2011). In addition, ECV-, BIV-, and CMTV-like viruses have been detected in several reptile species in captivity (Marschang et al. 2013; Stöhr et al. 2015). Characterization of these viruses has most often been based on partial MCP gene sequences, but additional sequence data are becoming available to help understand relationships between the ranaviruses found in reptiles. In the USA, only FV3-like viruses have been detected in reptiles so far, which is the most commonly reported ranavirus for anurans. In Europe, a wider range of ranavirus types has been described, including both FV3-like viruses as well as ECV, BIV, and CMTV representatives. A fully sequenced ranavirus from chelonians in Asia (soft-shelled turtle iridovirus, STIV) has been shown to be closely related to FV3 (Huang et al. 2009).

\subsection{History of Reptile Cases}

In the 1980s, two cases of iridovirus infections in tortoises were described in Switzerland (Heldstab and Bestetti 1982; Müller et al. 1988). Due to the described clinical, histological, and electronmicroscopical findings, these animals are believed to have been infected with a ranavirus and are therefore the first documented cases of ranaviral infection and disease in reptiles. A low number of proven detections of ranavirus infection in reptiles were documented in captive and wild chelonians in the late 1990s (Table 4). The first cases of ranavirus infections in reptiles from which data were available on the viral genome were from a box turtle (Terrapene $c$. carolina) and a tortoise (Testudo horsfieldii) from North America. Both appeared to be FV3-like based on partial MCP gene sequences and restriction endonuclease analysis (Mao et al. 1997). No clinical information on those two chelonians was 


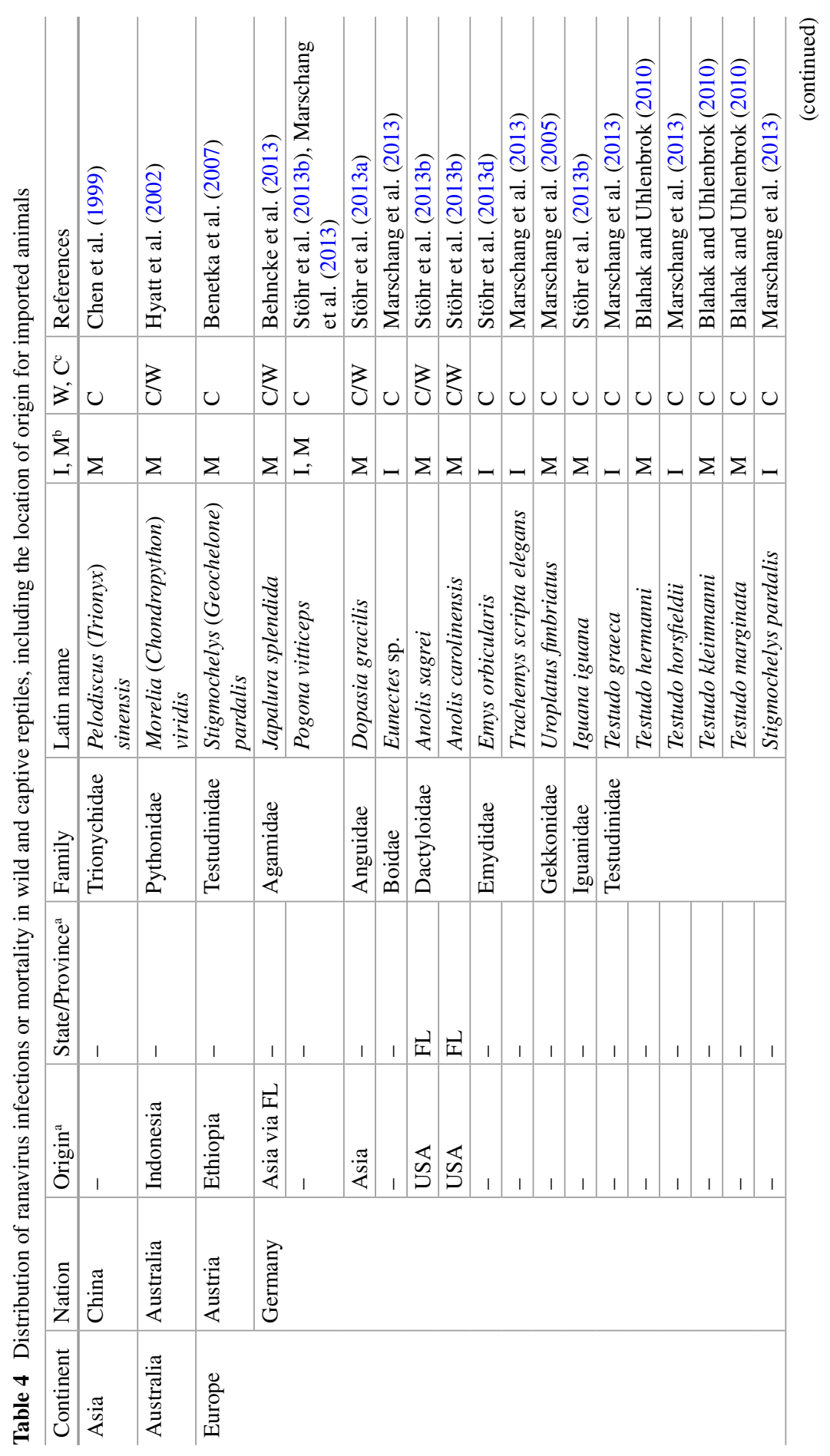




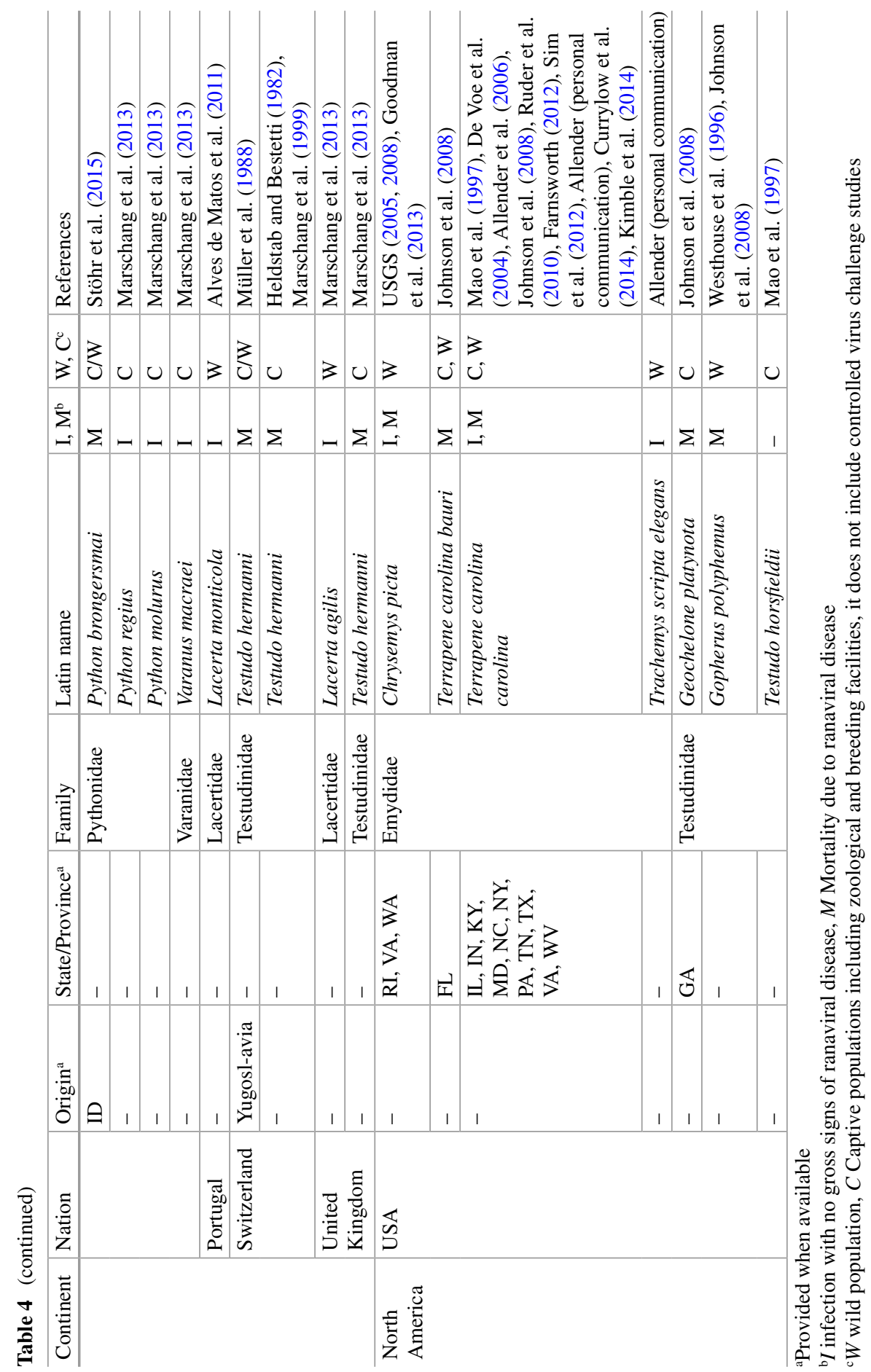


published. Recently, there has been an increase in the number of reports and cases in chelonians worldwide, especially box turtles (Terrapene sp.) in the USA (De Voe et al. 2004; Allender et al. 2006; Johnson et al. 2008; Allender 2012, Table 4). Although ranavirus detection in chelonians has been reported most frequently, detection of these viruses in lizards and snakes has been increasing, mostly from captive populations (Stöhr et al. 2013b; Behncke et al. 2013; Marschang et al. 2013). The causes for increased detection of ranaviruses in wild and captive reptiles may include increased awareness or surveillance, improved testing methods, or actual emergence of the pathogen.

\subsection{Outbreaks in Chelonians}

Adult chelonians have been more commonly reported to develop FV3-like infections than juveniles (Johnson 2006). However, recent surveillance in eastern box turtles demonstrated that juveniles are more likely to be FV3 positive (Allender 2012). Therefore, it is likely that susceptibility of chelonians to ranaviruses differs among developmental stages similar to amphibians (Haislip et al. 2011). Some outbreaks in box turtles have involved translocation events that congregate many individuals, resulting in high infection prevalence and death (Belzer and Seibert 2011; Farnsworth and Seigel 2013; Kimble et al. 2014). In a multiyear survey of box turtles in the USA, ranavirus prevalence has not been reported above $5 \%$ in a population without abnormal mortality events (Allender et al. 2013).

Reports of single cases and outbreaks in reptiles so far have mainly involved box turtles within North America (De Voe et al. 2004; Allender et al. 2006; Johnson et al. 2008, 2010; Ruder et al. 2010; Allender 2012; Kimble et al. 2014). While eastern box turtles are primarily terrestrial, they have been shown to spend a considerable amount of time in temporary ponds (Donaldson and Echternacht 2005), which may expose them to ranavirus through water or sympatric amphibians (Belzer and Seibert 2011; Currylow et al. 2014). Some studies have indicated that increased ranaviral mortality in box turtles may correlate with increased exposure to infected sympatric amphibians, possibly via predation on infected amphibians, exposure to water containing ranavirus shed by amphibians, or via hematophagous insects (Belzer and Seibert 2011; Kimble et al. 2014). A study of wild Eastern painted turtles, an aquatic species, in Virginia, USA, reported infection prevalence of 4.8 $31.6 \%$ in different ponds, with no apparent disease (Goodman et al. 2013).

Koch's postulates have been fulfilled for ranaviral disease in chelonians, including box turtles. Experimental challenge with FV3-like isolates from either Burmese star tortoises (Geochelone platynota) or eastern box turtles has resulted in high mortality in red-eared sliders (Johnson et al. 2007; Allender 2012). Characteristic clinical signs of nasal discharge and oral plaques were seen, but were inconsistent among individuals. Mortality rate and the presence of clinical signs were observed to be significantly greater in turtles exposed at $22{ }^{\circ} \mathrm{C}$ compared to $28{ }^{\circ} \mathrm{C}$, with corresponding increased viral copy number and shorter median survival time at lower temperatures (Allender et al. 2013). 
In addition to the box turtle cases described above, several other reports of FV3like infections have been seen in captive chelonians (Marschang et al. 1999; De Voe et al. 2004; Benetka et al. 2007; Johnson et al. 2008; Blahak and Uhlenbrok 2010, Table 4). Ranavirus infections were described in two juvenile diseased Hermann's tortoises (Testudo hermanni) in Germany using PCR. All seven animals in the affected group died with similar signs (Marschang et al. 1999). The associated virus was first described as FV3-like, but has since been shown to be more closely related to CMTV (Stöhr et al. 2015). A leopard tortoise (Stigmochelys (Geochelone) pardalis pardalis) with nasal discharge, stomatitis, and lethargy had concurrent ranavirus and herpes virus infection confirmed by PCR (Benetka et al. 2007). Ranaviruses have also been detected in association with mortality events in captive Hermann's tortoises, Egyptian tortoises (T. kleinmanni), and marginated tortoises ( $T$. marginata) in Germany. Affected animals developed stomatitis as well as splenic necrosis, enteritis, hepatitis, pancreatitis, and dermatitis in some cases (Blahak and Uhlenbrok 2010). Analysis of the genomes of the viruses associated with these outbreaks (tortoise ranavirus 1 and 2, ToRV-1 and-2) shows that sequence analysis clusters them closely with FV3, while their genomic arrangement resembles that of CMTV (Stöhr et al. 2015). Captive farmed soft-shelled turtles in China developed "red neck disease" associated with a ranavirus (Chen et al. 1999). Soft shell turtle iridovirus was the first reptilian ranavirus to be fully sequenced, demonstrating that it is FV3-like (Huang et al. 2009). Comparative studies of ranaviruses infecting chelonians have shown that both FV3and CMTV-like strains occur, and that strains from different outbreaks differ from one another and are often more closely related to previously described amphibian ranaviruses than to other reptile-derived ranaviruses (Stöhr et al. 2015).

The short- and long-term impacts of ranaviruses on chelonian populations are unknown. Population stability in the face of ranavirus outbreaks has been debated, particularly regarding vulnerable Eastern box turtles. Due to the low reproductive rate and long time to sexual maturation of these animals, loss of adult females due to this disease will likely lead to significant population declines over time (Farnsworth and Seigel 2013).

\subsection{Outbreaks in Squamates}

Until recently, ranaviruses were only rarely reported in squamate reptiles (snakes and lizards). The first report of ranaviruses in these animals was in a group of ten juvenile green tree pythons (Morelia (Chondropython) viridis) imported into Australia from Papua New Guinea with oral and hepatic lesions. A ranavirus that was $97 \%$ homologous to FV3 was isolated from pooled necropsy tissues (Hyatt et al. 2002). An FV3-like ranavirus was isolated from several organs of a red blood python (Python brongersmai) with similar pathology imported into Germany from Indonesia. The isolated ranavirus was most closely related to TFV, originally described in China (Stöhr et al. 2015). A leaf-tailed gecko (Uroplatus fimbriatus) died unexpectedly and was diagnosed with a BIV-like ranavirus infection 
(Marschang et al. 2005, Stöhr et al. 2015). In Portugal, a ranavirus was isolated from a wild-caught Iberian mountain lizard (Lacerta monticola) that did not show any clinical signs of disease. This isolate was closely related to FV3; a coinfection with erythrocytic necrosis virus was also found (Alves de Matos et al. 2011). In a study describing virological screening of samples from lizards (Stöhr et al. 2013b), ranaviral infections were detected in five species: brown anoles (Anolis sagrei), Asian glass lizards (Dopasia gracilis), green anoles (Anolis carolinensis), green iguanas (Iguana iguana), and a central bearded dragon (Pogona vitticeps). All of the infected lizards had skin lesions. Sequencing part of the MCP gene of each virus showed that the five detected viruses were distinct from one another and were 98.4$100 \%$ identical to the corresponding portion of the FV3 genome. However, the ranavirus detected in the green iguana was $100 \%$ identical to ECV, whereas the ranavirus found in the bearded dragon was identical to a ranavirus detected in tortoises in Germany (ToRV-1), which is most closely related to FV3 (Stöhr et al. 2015). Further analysis of the genomes of the isolated viruses demonstrated that the ranaviruses detected in anoles were closely related to FV3, whereas the isolate from the Asian glass lizard clustered phylogenetically to TFV (Stöhr et al. 2015). A ranavirus was also detected in green striped tree dragons (Japalura splendida) imported from southwestern China via Florida into Germany during a mass mortality event. The ranavirus appeared to be closely related to FV3 (Behncke et al. 2013). During a study in Germany, different reptilian samples submitted for virological testing were screened for the presence of ranavirus, with an increasing number of infections detected from 2010 to 2013. Affected species included various chelonian and squamate species (Table 4). Some of the detected ranaviruses were most closely related to $\mathrm{ECV}$, others clustered together with the previously detected ranaviruses in European amphibians or reptiles, and one virus was FV3-like (A. Stöhr, unpublished data). This increase in detection of ranaviruses in reptiles may reflect either true emergence of these viruses in reptiles or increased surveillance. The genomic differences found in the viruses studied indicate that there is not a single strain of ranavirus that has adapted to reptiles as hosts, but rather that multiple transmissions of ranaviruses from amphibians and fish to reptiles may have taken place (Jancovich et al. 2010), and may continue to occur. Interestingly, studies have shown that within the legal international trade of reptiles, the largest numbers are traded through Europe and that these include both captive bred and wild-caught animals (Bush et al. 2013). The majority of reptile infections with genetically diverse ranaviruses have also been reported in Europe, often with a connection to the pet trade (Stöhr et al. 2013b; Stöhr et al. 2015). The role of illegal trade in exotic pets for the epidemiology of ranaviral infections in reptiles has not been studied, although there is some indication that this has played a role in ranaviral outbreaks in pet reptiles as well (S. Blahak, CVUA-OWL, personal communication). Wild-caught and farmed reptiles that are globally traded are often in contact with other animal species (reptiles and amphibians), and are not regularly tested for the presence of infections. Another aspect of increased surveillance and reporting of ranaviral infections in reptiles is the increased finding of co-infections with other pathogens, making diagnosis of ranaviral disease in some cases difficult. 


\section{$5 \quad$ Interclass Transmission of Ranaviruses}

Ranaviruses, as described above, are pathogens that affect a wide variety of hosts across three classes of ectothermic vertebrates (Amphibia, Reptilia, and Osteichthyes). It has long been suspected that interclass transmission of this group of viruses was possible, but it has only recently been demonstrated experimentally under controlled laboratory conditions (Brenes et al. 2014a). Evidence exists that interclass transmission may occur in wild populations for at least BIV, ATV, and FV3.

The first evidence for interclass transmission of ranaviruses was provided by Moody and Owens (1994). Barramundi (Lates calcarifer) were exposed to BIV, an isolate derived from amphibians, by water bath exposure or injection. The exposed fish developed disease and experienced $100 \%$ mortality (Moody and Owens 1994). BIV has also successfully been transmitted to juvenile short-necked turtles (Emydura macquarii krefftii) and saw-shelled turtles (Myuchelys (Elseya) latisternum), but adult turtles of the same species as well as juvenile crocodiles (Crocodylus johnstoni) were not successfully infected. Transmission studies with three species of snakes (brown tree snakes, Boiga irregularis, common green tree snakes, Dendrelaphis punctulatus, and keelback snakes, Tropidonophis (Amphiesma) mairii) did not induce disease in any of the animals, but BIV was reisolated from one of the brown tree snakes four weeks after inoculation (Ariel 1997). The isolation of BIV so long after initial infection without clinical signs suggests that this species may be a viable reservoir (Ariel 1997).

Although originally thought to be restricted to urodeles (Jancovich et al. 2001), ATV was later shown to be pathogenic to anurans (Schock et al. 2008). Experimental infection of largemouth bass was successful, but inoculated animals experienced no mortality or disease (Picco et al. 2010). There is also evidence that multiple FV3like and ATV-like strains may circulate in ponds and may affect both urodeles and anurans (Schock et al. 2008). To date, no experimental infections of ATV in reptiles have been attempted.

An additional study by Bayley et al. (2013) has shown that a ranavirus originally isolated from fish (PPIV) is capable of causing mortality in common frog tadpoles. Common frog tadpoles were exposed to a panel of six fish-derived ranavirus isolates via water bath. However, only one of the six ranavirus isolates, PPIV, caused mortality. This was the first case where exposure to a fish-derived isolate caused death in an amphibian. Subsequent experiments by Brenes et al. (2014a) have shown transmission of an FV3-like isolate from fish to amphibians.

FV3-like viruses have been detected in fish, amphibians, and reptiles and there is evidence from wild populations, captive settings, and from experimental transmission studies that these viruses have a very wide host range. Mao et al. (1999a) found identical ranavirus isolates from a threespine stickleback and a northern red-legged frog (Rana aurora) tadpole from the same area. FV3-like viruses have been isolated from moribund marbled sleeper gobies (Oxyeleotris marmoratus) cultivated in Thailand (Prasankok et al. 2005) and several hatchery-reared sturgeon species during epizootics in the USA (Waltzek et al. 2014); however, the role of the virus in disease was only thoroughly studied and confirmed in pallid sturgeon. 
Brenes et al. (2014a) demonstrated water-bath transmission of an FV3-like virus, originally isolated from a moribund pallid sturgeon to amphibians (Cope's gray treefrog, Hyla chrysoscelis), fish (mosquito fish) and reptiles (red-eared sliders). In a similar experiment, three chelonians (Florida soft-shelled turtle, Apalone ferox; eastern river cooters, Pseudemys concinna; Mississippi map turtles, Graptemys pseudogeographica kohnii) were assessed for susceptibility to the same FV3-like virus, an FV3-like isolate from an eastern box turtle and a third FV3-like isolate from an American bullfrog, from the USA (Brenes et al. 2014b). While no disease or mortality was observed in these experiments, infections were documented in soft-shelled turtles that were exposed to the fish isolate and those that were exposed to the turtle isolate (Brenes et al. 2014b). Infections were also observed in the Mississippi map turtles that were exposed to the turtle isolate (Brenes et al. 2014b). These results demonstrate the possibility that reptiles, fish, and amphibians may act as reservoirs for FV3-like ranaviruses for other taxa.

The role of different host classes in the epidemiology of ranaviruses remains to be studied. A number of field studies have indicated that ranavirus infections in one group of hosts can affect the health and survival of sympatric ectothermic vertebrates, but the role of various hosts as long-term carriers of virus and in the dynamics of transmission is yet unknown. The fact that several studies have shown that different viruses may have vastly different effects on various hosts is also important for the assessment of infection status in clinically healthy animals, both in the wild and in captivity, especially in trade. Healthy infected animals in which ranaviruses are not suspected could be a source of infection via direct contact or environmental contamination for other susceptible species of other animal classes. All of these findings underscore the need to reassess our understanding of ranaviruses as multispecies pathogens, not only as pathogens of specific groups of animals.

\section{Summary and Conclusions}

Ranavirus infections in amphibians, fish, and reptiles are widespread and affect a diverse suite of species within these vertebrate classes (Table 1, Fig. 6). The species affected include some that are economically important (e.g., rainbow trout, softshelled turtle, bullfrogs), but also several that are of conservation concern (e.g., Chinese giant salamander, gopher tortoise, dusky gopher frog, pallid sturgeon). The economic and conservation risk of these multispecies pathogens is dependent upon many factors, including characteristics of the host species. One thing is certain - some host species are highly susceptible to ranavirus, and these species are most likely to be affected during outbreaks. Thus, understanding host susceptibility to different ranaviruses is key to quantifying risk. Host-pathogen interactions between ranaviruses and amphibians are the best characterized. Research in this area needs to continue, but there also needs to be greater attention on the role of reptiles and fish in ranavirus epizootic events. 

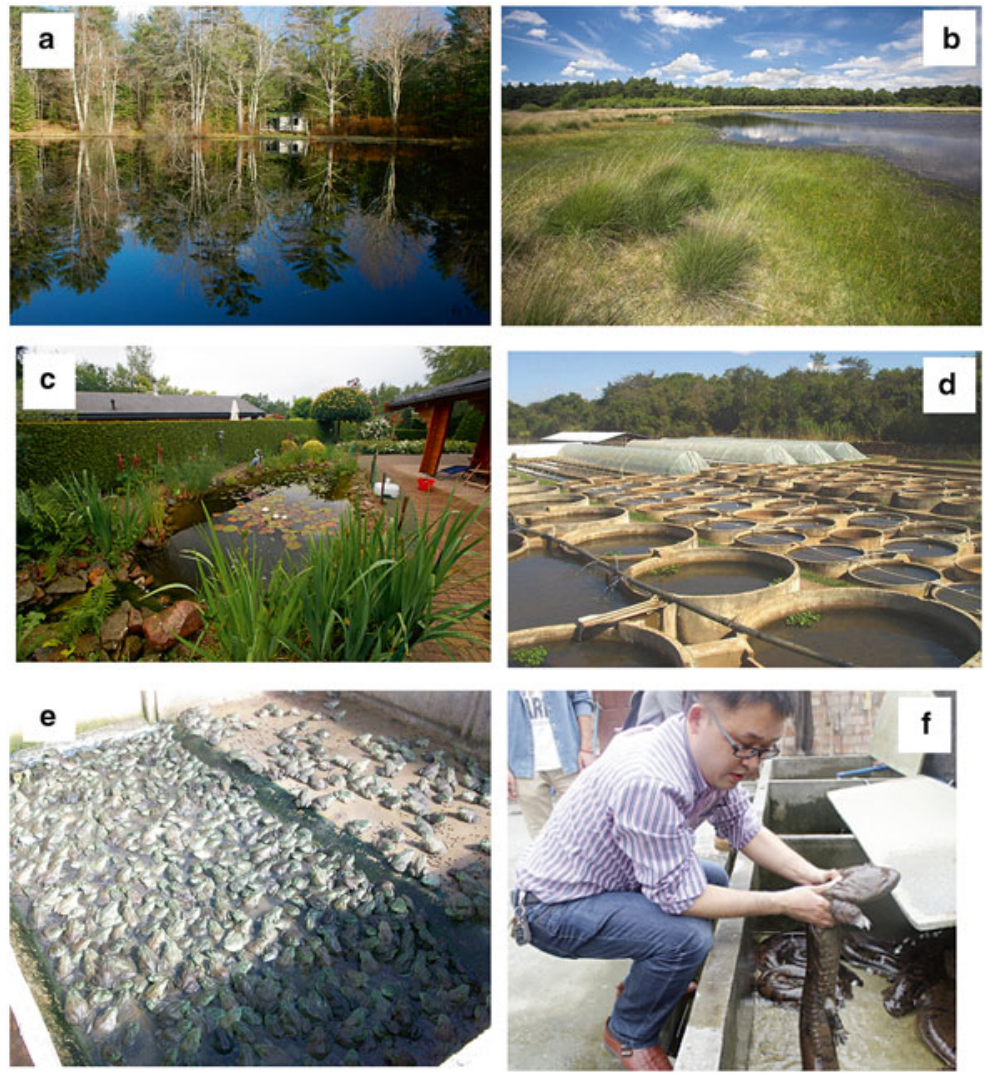

Fig. 6 Sites of ranavirus outbreaks include seemingly undisturbed sites, such as (a) Maine, USA (credit $=$ Nathaniel Wheelwright $)$ and $(\mathbf{b})$ Dwingelderveld, Netherlands (credit $=$ Jeiger Herder $),(\mathbf{c})$ constructed ponds in urban environments (credit $=$ Jeiger Herder), and $(\mathbf{d})$ aquaculture facilities (credit=Rolando Mazzoni). High host density and environmental stressors likely contribute to outbreaks, especially in captive facilities (e.g., (e) bullfrog farm in Brazil; credit=Rolando Mazzoni). Some highly endangered species (e.g., Andrias davidianus) have been affected (f), credit $=$ Yi Geng

All three classes of vertebrate hosts are intensively farmed in different regions of the world. The conditions of captive culture facilities that often maintain high densities of genetically similar individuals may be conducive to repeated outbreaks of ranaviral disease (Pearman and Garner 2005; Fig. 6). Additionally, conditions that favor transmission can lead to increased virulence, according to the virulence tradeoff hypothesis (Alizon et al. 2009). Thus, captive facilities with recurring ranavirus outbreaks may facilitate evolution of ranavirus types that are more virulent than wild types (Brunner et al. 2015). 
The commercial trade of ranavirus hosts is likely a significant factor facilitating the global distribution of ranaviruses, as well as interclass transmission of the pathogen. If novel strains of ranaviruses are introduced into naïve populations, experimental evidence suggests that there could be devastating effects (e.g., Pearman et al. 2004; Storfer et al. 2007; Hoverman et al. 2010). With the trade in animals being truly global and ranaviruses accompanying them (e.g., Schloegel et al. 2009; Kolby et al. 2014), it is important to understand what ranaviruses are being transported and where they end up.

Understanding the geographical distribution and host range of ranaviruses is becoming increasingly important as the World Health Organization for Animals has declared that EHNV and ranaviruses that infect amphibians are "reportable infections of wildlife" (OIE 2008). This designation requires countries that have agreed to OIE policies to screen a sample of ranavirus hosts that are crossing international borders for the presence of ranaviruses (Schloegel et al. 2010). However, few countries have yet taken steps to implement import policies that require declaration of ranavirus-free animals. Moreover, infection of fish by ranaviruses (other than EHNV) and reptiles (for any ranavirus species) are not included in the OIE regulations.

We are just beginning to understand the distribution and host range of ranaviruses. Continued surveillance of wild and captive populations, as well as, commercially traded animals combined with the characterization of the ranavirus strains are necessary to fully understand the distribution and host diversity of ranaviruses. Therefore, when ranavirus studies are undertaken, sufficient funding should be obtained to at least partially characterize the virus if detected. This approach will require that researchers work in interdisciplinary groups.

Acknowledgments Funding has been provided by a President's Initiative Faculty Development Grant Type A to ALJD.

The authors would like to thank Jesse Brunner (Washington State University) and two anonymous referees for their comments on previous versions of this manuscript.

Open Access publication was made possible through grants provided by the University of Tennessee (Institute of Agriculture, Office of Research and Engagement, and Department of Forestry, Wildlife, and Fisheries), Washington State University Libraries, Gordon State College (Office of Academic Affairs), the Association of Reptilian and Amphibian Veterinarians, and the Amphibian and Reptile Conservancy.

Open Access This chapter is distributed under the terms of the Creative Commons Attribution Noncommercial License, which permits any noncommercial use, distribution, and reproduction in any medium, provided the original author(s) and source are credited.

\section{References}

Ahne W, Schlotfeldt HJ, Thomsen I (1989) Fish viruses: isolation of an icosahedral cytoplasmic deoxyribovirus from sheatfish (Silurus glanis). J Vet Med B 36:333-336

Ahne W, Ogawa M, Schlotfeldt HJ (1990) Fish viruses: transmission and pathogenicity of an icosahedral cytoplasmic deoxyribovirus isolated from sheatfish (Silurus glanis). J Vet Med B $37: 187-190$ 
Ahne W, Schlotfeldt HJ, Ogawa M (1991) Iridovirus infection of adult sheatfish (Silurus glanis). Bull Eur Assoc Fish Pathol 11:97-98

Alizon S, Hurford A, Mideo N et al (2009) Virulence evolution and the trade-off hypothesis: history, current state of affairs and the future. J Evol Biol 22:245-259

Allender MC (2012) Characterizing the epidemiology of ranavirus in North American chelonians: diagnosis, surveillance, pathogenesis, and treatment. Ph.D. Thesis, Department of Veterinary Clinical Medicine, University of Illinois at Urbana-Champaign, Urbana, p 219

Allender MC, Fry MM, Irizarry AR et al (2006) Intracytoplasmic inclusions in circulating leukocytes from an eastern box turtle (Terrapene carolina carolina) with iridoviral infection. J Wildl Dis 42:677-684

Allender MC, Abd-Eldaim M, Schumacher J et al (2011) PCR prevalence of ranavirus in freeranging eastern box turtles (Terrapene carolina carolina) at rehabilitation centers in three southeastern US states. J Wildl Dis 47:759-764

Allender MC, Mitchell MA, McRuer D et al (2013) Prevalence, clinical signs, and natural history characteristics of frog virus 3-like infections in eastern box turtles (Terrapene carolina carolina). Herpetol Conserv Biol 8:308-320

Alves de Matos AP, Caeiro MF, Marschang RE et al (2008) Adaptation of ranaviruses from Peneda-Gerês National Park (Portugal) to cell cultures and their characterizations. Microsc Microanal 14:139-140

Alves de Matos AP, Caeiro MF, Papp R et al (2011) New viruses from Lacerta monticola (Serra da Estrela, Portugal): further evidence for a new group of nucleo-cytoplasmic large deoxyriboviruses. Microsc Microanal 17:101-108

Ariel E (1997) Pathology and serological aspects of Bohle iridovirus infections in six selected water-associated reptiles in North Queensland. Ph.D. Thesis, Department of Microbiology and Immunology, James Cook University, North Queensland, p 168

Ariel, E. \& Bang-Jensen, B. 2009. Challenge studies of European stocks of redfin perch, Perca fluviatilis L., and rainbow trout, Oncorhynchus mykiss (Walbaum), with epizootic haematopoietic necrosis virus. Journal of Fish Diseases, 32, 1017-1025

Ariel E, Owens L (1997) Epizootic mortalities in tilapia Oreochromis mossambicus. Dis Aquat Organ 29:1-6

Ariel E, Kielgas J, Svart HE et al (2009) Ranavirus in wild edible frogs, Pelophylax kl. esculentus in Denmark. Dis Aquat Organ 85:7-14

Ariel E, Holopainen R, Olesen NJ et al (2010) Comparative study of ranavirus isolates from cod (Gadus morhua) and turbot (Psetta maxima) with reference to other ranaviruses. Arch Virol 155:1261-1271

Balseiro A, Dalton KP, Cerrol A et al (2009) Pathology, isolation and molecular characterization of a ranavirus from the common midwife toad Alytes obstetricans on the Iberian Peninsula. Dis Aquat Organ 84:95-104

Balseiro A, Dalton KP, Cerro A et al (2010) Outbreak of common midwife toad virus in alpine newts (Mesotriton alpestris cyreni) and common midwife toads (Alytes obstetricans) in northern Spain: comparative pathological study of an emerging ranavirus. Vet J 186:256-258

Bang-Jensen B, Ersboll AK, Ariel E (2009) Susceptibility of pike Esox lucius to a panel of Ranavirus isolates. Dis Aquat Organ 83:169-179

Bang-Jensen B, Holopainen R, Tapiovaara H et al (2011a) Susceptibility of pike-perch Sander lucioperca to a panel of ranavirus isolates. Aquaculture 313:24-30

Bang-Jensen B, Reschova S, Cinkova K et al (2011b) Common carp (Cyprinus carpio) and goldfish (Carassius auratus) were not susceptible to challenge with ranavirus under certain challenge conditions. Bull Eur Assoc Fish Pathol 31:112-118

Bayley AE, Hill BJ, Feist SW (2013) Susceptibility of the European common frog Rana temporaria to a panel of ranavirus isolates from fish and amphibian hosts. Dis Aquat Organ 103:171-183

Becker JA, Tweedie A, Gilligan D et al (2013) Experimental infection of Australian freshwater fish with epizootic haematopoietic necrosis virus (EHNV). J Aquat Anim Health 25:66-76

Behncke H, Stöhr AC, Heckers KO et al (2013) Mass mortality in green striped tree dragons (Japalura splendida) associated with multiple viral infections. Vet Rec 173:248 
Belzer WR, Seibert S (2011) A natural history of Ranavirus in an eastern box turtle population. Turtle Tortoise Newsl 15:18-25

Benetka V, Grabensteiner E, Gumpenberger M et al (2007) First report of an iridovirus (Genus Ranavirus) infection in a Leopard tortoise (Geochelone pardalis pardalis). Wien Tierarztl Monatsschr 94:243-248

Bigarré L, Cabon J, Baud M et al (2008) Ranaviruses associated with high mortalities in catfish in France. Bull Eur Assoc Fish Pathol 28:163-168

Blahak S, Uhlenbrok C (2010) Ranavirus infections in European terrestrial tortoises in Germany. In: Öfner S, Weinzierl F (eds) Proceedings of the 1st international conference on reptile and amphibian medicine, Munich, Germany, 4-7 March 2010, pp 17-23

Bollinger RK, Mao J, Schock DM et al (1999) Pathology, isolation, and preliminary molecular characterization of a novel iridovirus from tiger salamanders in Saskatchewan. J Wildl Dis 35:413-429

Bovo G, Comuzzi M, De Mas S et al (1993) Isolation of an irido-like viral agent from breeding cat fish (Ictalurus melas). Boll Soc It Patol Ittica 11:3-10

Bovo G, Giacometti P, Montesi F et al (1999) Isolation of an irido-like agent from New Zealand eel. In: Proceedings of the European Association of Fish Pathologists, Rhodes, Greece, p 53

Brenes R, Gray MJ, Waltzek TB et al (2014a) Transmission of ranavirus between ectothermic vertebrate hosts. PLoS One 9:e92476

Brenes R, Miller DL, Waltzek TB et al (2014b) Susceptibility of fish and turtles to three ranaviruses isolated from different ectothermic vertebrate classes. J Aquat Anim Health 26:118-126

Brunner JL, Barnet KE, Gosier CJ et al (2011) Ranavirus infection in die-offs of vernal pool amphibians in New York, USA. Herpetol Rev 42:76-79

Brunner JL, Storfer A, Gray MJ, Hoverman JT (2015) Ranavirus ecology and evolution: from epidemiology to extinction. In: Gray MJ, Chinchar VG (eds) Ranaviruses: lethal pathogens of ectothermic vertebrates. Springer, New York

Bush ER, Baker SE, MacDonald DW (2013) Global trade in exotic pets 2006-2012. Conserv Biol 28:663-676

Chen ZX, Zheng JC, Jiang YL (1999) A new iridovirus isolated from soft-shelled turtle. Virus Res 63:147-151

Chen Z, Gui X, Gao C et al (2013) Genome architecture changes and major gene variations of Andrias davidianus ranavirus (ADRV). Vet Res 44:101

Cheng K, Jones MEB, Jancovich JK et al (2014) Isolation of a Bohle iridovirus-like agent from boreal toads housed within a cosmopolitan aquarium collection. Dis Aquat Organ 111(2):139-152

Chinchar VG (2002) Ranaviruses (family Iridoviridae): emerging cold-blooded killers. Arch Virol $147: 447-470$

Chinchar VG, Waltzek TB (2014) Ranaviruses: not just for frogs. PLoS Pathog 10:e1003850

Chua FHC, Ng ML, Ng KL et al (1994) Investigation of outbreaks of a novel disease, 'Sleepy Grouper Disease', affecting the brown-spotted grouper, Epinephelus tauvina Forskal. J Fish Dis 17:417-427

Clark HF, Brennan JC, Zeigel RF et al (1968) Isolation and characterization of viruses from the kidneys of Rana pipiens with renal adenocarcinoma before and after passage in the red eft (Triturus viridescens). J Virol 2:629-640

Collins JP, Jones TR, Berna HJ (1988) Conserving genetically distinct populations: the case of the Huachuca tiger salamander (Ambystoma tigrinum stebbinsi Lowe). In: Proceedings of the symposium on management of amphibians, reptiles and small mammals in North America, Flagstaff, Arizona, 19-21 July 1988

Converse KA, Green DE (2005) Diseases of tadpoles. In: Majumadar SK, Huffman JE, Brenner FJ et al (eds) Wildlife diseases: landscape epidemiology, spatial distribution and utilization of remote sensing techniques. The Pennsylvania Academy of Science, Easton, pp 72-88

Cullen BR, Owens L (2002) Experimental challenge and clinical cases of Bohle iridovirus (BIV) in native Australian anurans. Dis Aquat Organ 49:83-92 
Cullen BR, Owens L, Whittington RJ (1995) Experimental infection of Australian anurans (Limnodynastes terraereginae and Litoria latopalmata) with Bohle iridovirus. Dis Aquat Organ 23:83-92

Cunningham AA, Langton TES, Bennett PM et al (1993) Unusual mortality associated with poxvirus-like particles in frogs (Rana temporaria). Vet Rec 133:141-142

Cunningham AA, Langton TES, Bennet PM et al (1996) Pathological and microbial findings from incidents of unusual mortality on the common frog (Rana temporaria). Philos Trans R Soc Lond B Biol Sci 315:1539-1557

Cunningham AA, Hyatt AD, Russell P et al (2007) Experimental transmission of a ranavirus disease of common toads (Bufo bufo) to common frogs (Rana temporaria). Epidemiol Infect 135:1213-1216

Cunningham AA, Turvey ST, Zhou F (2015) Development of the Chinese giant salamander Andrias davidianus farming industry in Shaanxi Province, China: conservation threats and opportunities. Oryx doi:10.1017/S0030605314000842.

Currylow AF, Johnson AJ, Williams RN (2014) Evidence of ranavirus infections among sympatric larval amphibians and box turtles. J Herpetol 48:117-121

Daszak P, Berger L, Cunningham AA et al (1999) Emerging infectious diseases and amphibian population declines. Emerg Infect Dis 6:735-748

Davidson SRA, Chambers DL (2011) Ranavirus prevalence in amphibian populations of Wise County, Virginia, USA. Herpetol Rev 42:214-215

De Voe RK, Geissler K, Elmore S et al (2004) Ranavirus-associated morbidity and mortality in a group of captive eastern box turtles (Terrapene carolina carolina). J Zoo Wildl Med 35:534-543

Deng G, Li S, Xie J, Bai J et al (2011) Characterization of a ranavirus isolated from cultured largemouth bass (Micropterus salmoides) in China. Aquaculture 312:198-204

Docherty DE, Meteyer CU, Wang J et al (2003) Diagnostic and molecular evaluation of three iridovirus associated salamander mortality events. J Wildl Dis 39:556-566

Docherty-Bone TM, Ndifon RK, Nyingchia ON et al (2013) Morbidity and mortality of the critically endangered Lake Oku clawed frog (Xenopus longipes). Endanger Species Res 21:115-128

Donaldson BM, Echternacht AC (2005) Aquatic habitat use relative to home range and seasonal movement of Eastern box turtles (Terrapene carolina carolina: Emydidae) in Eastern Tennessee. J Herpetol 39:278-284

Driskell EA, Miller DL, Swist SL et al (2009) PCR detection of ranavirus in adult anurans from the Louisville Zoological Gardens. J Zoo Wildl Med 40:559-563

Drury SEN, Gough RE, Cunningham AA et al (1995) Isolation of an iridovirus-like agent from common frogs (Rana temporaria). Vet Rec 137:72-73

Duffus ALJ, Cunningham AA (2010) Major disease threats to European amphibians. Herpetol J 20:117-127

Duffus ALJ, Pauli PD, Wozney K et al (2008) Frog virus 3-like infections in aquatic amphibian communities. J Wildl Dis 44:109-120

Duffus ALJ, Nichols RA, Garner TWJ (2013) Investigations into the life history stages of the common frog (Rana temporaria) affected by an amphibian ranavirus in the United Kingdom. Herpetol Rev 44:460-463

Duffus ALJ, Nichols RA, Garner TWJ, 2014. Detection off a frog virus 3-like ranavirus in native and introduced amphibians in the United Kingdom in 2007 and 2008. Herpetol Rev 45:608-610

Earl JE, Gray MJ (2014) Introduction of ranavirus to isolated wood frog populations could cause local extinction. Ecohealth. doi:10.1007/s10393-014-0950-y

Eaton HE, Metcalf J, Penny E, Tcherepanov V, Upton C, Brunetti CR (2007) Comparative genomic analysis of the family Iridoviridae: re-annotating and defining the core set of iridovirus genes. Virol J 4:11-28

Echaubard P, Little K, Pauli B, Lesbarrères D (2010) Context-dependent effects of ranaviral infection on northern leopard frog life history traits. PLoS One 5:e13723 
Farnsworth SD (2012) On-site and off-site translocations of eastern box turtles (Terrapene carolina carolina): Comparisons of survival and overwintering ecology. MSc Thesis, Department of Biological Sciences, Towson University, Towson, MD, USA. http://www.academia.edu/5781810/ ON-SITE_AND_OFF-SITE_TRANSLOCATIONS_OF_EASTERN_BOX_TURTLES_ TERRAPENE_CAROLINA_CAROLINA_COMPARISONS_OF_SURVIVAL_AND_ OVERWINTERING_ECOLOGY

Farnsworth SD, Seigel RA (2013) Responses, movements, and survival of relocated box turtles during construction of the intercounty connector highway in Maryland. Transp Res Rec 2362:1-8. doi:10.3141/2362-01

Fijan N, Matasin Z, Petrinec Z et al (1991) Isolation of an iridovirus-like agent from the green frog (Rana esculenta L.). Vet Arch Zagreb 61:151-158

Forzán M, Wood J (2013) Low detection of ranavirus DNA in wild postmetamorphic green frogs, Rana (Lithobates) clamitans, despite previous or concurrent tadpole mortality. J Wildl Dis 49:879-886

Fox SF, Greer AL, Tores-Cervantes R et al (2006) First case of ranavirus-associated morbidity and mortality in natural populations of the South American frog, Atelognathus patagonicus. Dis Aquat Organ 72:87-92

Francis-Floyd R (1992) Comparative hematology for largemouth bass (Micropterus salmoides) and black crappie (Pomoxis nigromaculatus) from Lake Weir, Lake Holy, and Newman's Lake. Final report. Florida Freshwater Game and Fish Commission, Tallahassee

Gahl MK, Calhoun AJK (2010) The role of multiple stressors in ranavirus-caused amphibian mortalities in Acadia National Park wetlands. Can J Zool 88:108-118

Galli L, Pereira A, Márquez A et al (2006) Ranavirus detection by PCR in cultured tadpoles (Rana catesbeiana Shaw, 1802) from South America. Aquaculture 257:78-82

Geng Y, Wang KY, Zhou ZY et al (2011) First report of a ranavirus associated with morbidity and mortality in farmed Chinese giant salamanders. J Comp Pathol 145:95-112

George, MR, John KR, Mansoor MM, Saravanakumar R, Sundar P, Pradeep V (2014) Isolation and characterization of a ranavirus from koi, Cyprinus carpio L., experiencing mass mortalities in India. J Fish Dis. doi:10.1111/jfd.12246

Glenney JW, Julian JT, Quartz WM (2010) Preliminary amphibian health survey in the Delaware Water Gap National Recreation Area. J Aquat Anim Health 22:102-114

Gobbo F, Cappellozza E, Pastore MR et al (2010) Susceptibility of black bullhead Ameiurus melas to a panel of ranavirus isolates. Dis Aquat Organ 90:167-174

Goldberg TL (2002) Largemouth bass virus: an emerging problem for warmwater fisheries? In: Philipp DP, Ridgway MS (eds) Black bass: ecology, conservation and management. American Fisheries Society Symposium, Bethesda

Goodman RM, Miller DL, Ararso YT (2013) Prevalence of ranavirus in Virginia turtles as detected by tail-clip sampling versus oral-cloacal swabbing. Northeast Nat 20:325-332

Granoff A, Came PE, Rafferty KA (1965) The isolation and properties of viruses from Rana pipiens: their possible relationship to the renal adenocarcinoma of the leopard frog. Ann N Y Acad Sci 126:237-255

Grant EC, Inendino KR, Love WJ et al (2005) Effects of practices related to catch-and-release angling on mortality and viral transmission in juvenile largemouth bass infected with largemouth bass virus. J Aquat Anim Health 17:315-322

Gray MJ, Miller DL, Schmuster AC et al (2007) Frog virus 3 prevalence in tadpole populations at cattle-access and non-access wetlands in Tennessee, USA. Dis Aquat Organ 77:97-103

Gray MJ, Miller DL, Hoverman JT (2009a) Ecology and pathology of amphibian ranaviruses. Dis Aquat Organ 87:243-266

Gray MJ, Miller DL, Hoverman JT (2009b) First report of ranavirus infecting lungless salamanders. Herpetol Rev 40:316-319

Gray MJ, Brunner JL, Earl JE, Ariel E (2015) Design and analysis of ranavirus studies: surveillance and assessing risk. In: Gray MJ, Chinchar VG (eds) Ranaviruses: lethal pathogens of ectothermic vertebrates. Springer, New York 
Green DE, Converse KA (2005) Diseases of frogs and toads. In: Majumadar SK, Huffman JE, Brenner FJ et al (eds) Wildlife diseases: landscape epidemiology, spatial distribution and utilization of remote sensing techniques. The Pennsylvania Academy of Science, Easton, pp 89-117

Green DE, Converse KA, Schrader AK (2002) Epizootiology of sixty-four amphibian morbidity and mortality events in the USA, 1996-2001. Ann N Y Acad Sci 969:323-339

Greer AL, Berrill M, Wilson PJ (2005) Five amphibian mortality events associated with ranavirus infection in south central Ontario, Canada. Dis Aquat Organ 67:9-14

Greer AL, Brunner JL, Collins JP (2009) Spatial and temporal patterns of Ambystoma tigrinum virus (ATV) prevalence in tiger salamanders Ambystoma tigrinum nebulosum. Dis Aquat Organ 85:1-6

Grizzle JM, Brunner CJ (2003) Review of largemouth bass virus. Fisheries 28:10-14

Grizzle JM, Altinok I, Fraser WA et al (2002) First isolation of largemouth bass virus. Dis Aquat Organ 50:233-235

Groocock GH, Grimmett SG, Getchell RG et al (2008) A survey to determine the presence and distribution of largemouth bass virus in wild freshwater bass in New York State. J Aquat Anim Health 20:158-164

Haislip NA, Gray MJ, Hoverman JT et al (2011) Development and disease: how susceptibility to an emerging pathogen changes through anuran development. PLoS One 6:e22307

Hamed MK, Gray MJ, Miller DL (2013) First report of ranavirus in plethodontidae salamanders from the Mount Rogers National Recreation Area, Virginia, USA. Herpetol Rev 44:455-457

Hanson LA, Petrie-Hansons L, Meals KO et al (2001) Persistence of large-mouth bass virus infection in a northern Mississippi reservoir after a die-off. J Aquat Anim Health 13:27-34

Harp EM, Petranka JW (2006) Ranavirus in wood frogs (Rana sylvatica): potential sources of transmission within and between ponds. J Wildl Dis 42:307-318

Heard MJ, Smith KF, Ripp KJ et al (2013) The threat of disease increases as species move towards extinction. Conserv Biol 24:1378-1388

Hedrick RP, McDowell TS (1995) Properties of iridoviruses from ornamental fish. Vet Res 26:423-427

Heldstab A, Bestetti G (1982) Spontaneous viral hepatitis in a spur-tailed Mediterranean land tortoise. J Zoo Anim Med 13:113-120

Holopainen R, Ohlemeyer S, Schuetze H et al (2009) Ranavirus phylogeny and differentiation based on major capsid protein, DNA polymerase and neurofilament triplet H1-like protein genes. Dis Aquat Organ 85:81-91

Homan RN, Bartling JR, Stenger RJ et al (2013) Detection of ranavirus in Ohio, USA. Herpetol Rev 44:615-618

Hoverman JT, Gray MJ, Miller DL (2010) Anuran susceptibility to ranaviruses: role of species identity, exposure route and a novel virus isolate. Dis Aquat Organ 98:97-107

Hoverman JT, Gray MJ, Haislip NA et al (2011) Phylogeny, life history, and ecology contribute to differences in amphibian susceptibility to ranaviruses. Ecohealth 8:301-319

Hoverman JT, Gray MJ, Haislip NA et al (2012a) Widespread occurrence of ranavirus in pond breeding amphibian populations. Ecohealth 9:36-48

Hoverman JT, Mihaljevic JR, Richgels LD et al (2012b) Widespread co-occurrence of virulent pathogens within California amphibian communities. Ecohealth 9:288-292

Huang Y, Huang X, Liu H et al (2009) Complete sequence determination of a novel reptile iridovirus isolated from soft-shelled turtle and evolutionary analysis of Iridoviridae. BMC Genomics $10: 224$

Huang SM, Tu C, Tseng CH et al (2011) Genetic analysis of fish iridoviruses isolated in Taiwan during 2001-2009. Arch Virol 156:1505-1515

Hyatt AD, Gould AR, Zupanovic Z et al (2000) Comparative studies of piscine and amphibian iridoviruses. Arch Virol 145:301-331

Hyatt AD, Williamson M, Coupar BEH et al (2002) First identification of a ranavirus from green pythons (Chondropython viridis). J Wildl Dis 38:239-252 
Iwanowicz L, Densmore C, Hahn C et al (2013) Identification of largemouth bass virus in the introduced Northern snakehead inhabiting the Chesapeake Bay Watershed. J Aquat Anim Health 25:191-196

Jancovich JK, Davidson EW, Morado JF et al (1997) Isolation of a lethal virus from the endangered tiger salamander Ambystoma tigrinum stebbinsi. Dis Aquat Organ 31:161-167

Jancovich JK, Davidson EW, Seiler A et al (2001) Transmission of the Ambystoma tigrinum virus to alternative hosts. Dis Aquat Organ 46:159-163

Jancovich JK, Davidson EW, Parameswaran N et al (2005) Evidence for emergence of an amphibian iridoviral disease because of human-enhanced spread. Mol Ecol 14:213-224

Jancovich JK, Bremont M, Touchman JW et al (2010) Evidence for multiple recent host species shifts among the ranaviruses (family Iridoviridae). J Virol 84:2636-2647

Jancovich JK, Steckler N, Waltzek TB (2015) Ranavirus taxonomy and phylogeny. In: Gray MJ, Chinchar VG (eds) Ranaviruses: lethal pathogens of ectothermic vertebrates. Springer, New York

Johnson AJ (2006) Iridovirus infections of captive and free-ranging chelonians in the United States. Ph.D. Thesis, Veterinary Medicine. University of Florida, Gainesville, p 149

Johnson AJ, Pessier AP, Jacobson ER (2007) Experimental transmission and induction of ranaviral disease in western ornate box turtles (Terrapene ornata ornata) and red-eared sliders (Trachemys scripta elegans). Vet Pathol 44:285-297

Johnson AJ, Pessier AP, Wellehan JFX et al (2008) Ranavirus infection of free-ranging and captive box turtles and tortoises in the United States. J Wildl Dis 44:851-863

Johnson AJ, Wendland L, Norton TM et al (2010) Development and use of an indirect enzymelinked immunosorbent assay for detection of iridovirus exposure in gopher tortoises (Gopherus polyphemus) and eastern box turtles (Terrapene carolina carolina). Vet Microbiol 142:160-167

Juhász T, Woynarovichne LM, Csaba G et al (2013) Isolation of ranavirus causing mass mortality in brown bullheads (Ameiurus nebulosus) in Hungary. Magyar Allatorvosok Lapja $135: 763-768$

Kanchanakhan S (1998) An ulcerative disease of the cultured tiger frog, Rana tigrina, in Thailand: virological examination. AAHRI Newsl 7:1-2

Kik M, Martel A, Spitzen-van der Sluijs A et al (2011) Ranavirus associated mass mortality in wild amphibians in the Netherlands, 2010: a first report. Vet J 190:284-286

Kik M, Stege M, Boonyarittichaikij R et al (2012) Concurrent ranavirus and Batrachochytrium dendrobatidis infection in captive frogs (Phyllobates and Dendrobates species), the Netherlands, 2012: a first report. Vet J 194:247-249

Kimble SJ, Karna AK, Johnson AJ et al (2014) Mosquitoes as a potential vector of ranavirus transmission in terrestrial turtles. EcoHealth. doi:10.1007/s10393-014-0974-3

Kolby JE, Smith KM, Berger L et al (2014) First evidence of amphibian chytrid fungus (Batrachochytrium dendrobatidis) and ranavirus in Hong Kong amphibian trade. PLoS One 9:e90750

Landsberg JH, Kiryu Y, Tabuchi M et al (2013) Co-infection by alveolate parasites and frog virus 3-like ranavirus during and amphibian larval mortality event in Florida, USA. Dis Aquat Organ 105:89-99

Langdon, JS (1989) Experimental transmission and pathogenicity of epizootic hematopoietic necrosis virus (ehnv) in redfin perch, perca-fluviatilis 1 and 11 other teleosts. Journal of Fish Diseases, 12, 295-310

Langdon JS, Humphrey JD (1987) Epizootic haematopoietic necrosis a new viral disease in redfin perch Perca fluviatilis L. in Australia. J Fish Dis 10:289-298

Langdon JS, Humphrey JD, Copland J et al (1986a) The disease status of Australian salmonids: viruses and viral diseases. J Fish Dis 9:129-135

Langdon JS, Humphrey JD, Williams LM et al (1986b) First virus isolation from Australian fish: an iridovirus-like pathogen from redfin perch, Perca fluviatilis L. J Fish Dis 9:263-268

Langdon JS, Humphrey JD, Williams LM (1988) Outbreaks of an EHNV-like iridovirus in cultured rainbow trout, Salmo gairdneri Richardson, in Australia. J Fish Dis 11:93-96 
Lei X-Y, Ou T, Zhu R-L et al (2012) Sequencing and analysis of the complete genome of Rana grylio virus (RGV). Arch Virol 157:1559-1564

Leimbach S, Schütze H, Bergmann SM (2014) Susceptibility of European sheatfish Silurus glanis to a panel of ranaviruses. J Appl Ichthyol 30:93-101

Ma J, Zeng L, Zhou Y et al (2014) Ultrastructural morphogenesis of an amphibian iridovirus isolated from Chinese giant salamander (Andrias davidianus). J Comp Pathol 150:325-331

Majji S, LaPatra S, Long SM et al (2006) Rana catesbeiana virus Z (RCV-Z): a novel pathogenic ranavirus. Dis Aquat Organ 73:1-11

Mao J, Hedrick RP, Chinchar VG (1997) Molecular characterization, sequence analysis, and taxonomic position of newly isolated fish iridoviruses. Virology 229:212-220

Mao JD, Green E, Fellers G et al (1999a) Molecular characterization of iridoviruses isolated from sympatric amphibians and fish. Virus Res 63:45-52

Mao JH, Wang J, Chinchar GD et al (1999b) Molecular characterization of a ranavirus isolated from largemouth bass Micropterus salmoides. Dis Aquat Organ 37:107-114

Marschang RE, Becher P, Posthaus H et al (1999) Isolation and characterization of an iridovirus from Hermann's tortoises (Testudo hermanni). Arch Virol 144:1909-1922

Marschang RE, Braun S, Becher P (2005) Isolation of a ranavirus from a gecko (Uroplatus fimbriatus). J Zoo Wildl Med 36:295-300

Marschang RE, Stöhr AC, Blahak S et al (2013) Ranaviruses in snakes, lizards, and chelonians. In: Proceedings of second international symposium on ranaviruses, Knoxville, 27-29 July

Marsh IB, Whittington RJ, O'Rourke B et al (2002) Rapid differentiation of Australian, European and American ranaviruses based on variation in major capsid protein gene sequence. Mol Cell Probes 16:137-151

Martel A, Fard MS, van Rooij P et al (2012) Road-killed common toads (Bufo bufo) in Flanders (Belgium) reveal low prevalence of ranavirus and Batrachochytrium dendrobatidis. J Wildl Dis 48:835-839

Mavian C, Lopez-Bueno A, Balseiro A et al (2012) The genome sequence of the emerging common midwife toad virus identifies an evolutionary intermediate within ranaviruses. J Virol $86: 3617-3625$

Mazzoni R, José de Mesquita A, Fleury LFF et al (2009) Mass mortality associated with frog virus 3-like ranavirus infection in farmed tadpoles, Rana catesbeiana, from Brazil. Dis Aquat Organ 86:181-191

Miller DL, Rajeev S, Gray MJ et al (2007) Frog virus 3 infection, cultured American bullfrogs. Emerg Infect Dis 13:342-343

Miller DL, Rajeev S, Brookins M et al (2008) Concurrent infection with Ranavirus, Batrachochytrium dendrobatidis, and Aeromonas in a captive amphibian colony. J Zoo Wildl Med 39:445-449

Miller DL, Gray MJ, Rajeev S et al (2009) Pathological findings in larval and juvenile anurans inhabiting farm ponds in Tennessee, USA. J Wildl Dis 45:314-324

Miller D, Gray M, Storfer A (2011) Ecopathology of ranaviruses infecting amphibians. Viruses 3:2351-2373

Miller DL, Pessier AP, Hick P, Whittington RJ (2015) Comparative pathology of ranaviruses and diagnostic techniques. In: Gray MJ, Chinchar VG (eds) Ranaviruses: lethal pathogens of ectothermic vertebrates. Springer, New York

Monson-Collar K, Hazard L, Dolcemascolo P (2013) A Ranavirus-related mortality recent and the first report of Ranavirus in New Jersey. Herpetol Rev 44:263-265

Moody NJG, Owens L (1994) Experimental demonstration of pathogenicity of a frog virus, Bohle iridovirus, for fish species, barramundi Lates calcifer. Dis Aquat Organ 18:95-102

Müller M, Zangger N, Denzler T (1988) Iridovirus-epidemie bei der griechischen landschildkröte (Testudo hermanni hermanni). Verhandl Ber 30. Int Symp Erkr Zoo- und Wildtiere, Sofia, pp 271-274

Murali S, Wu MF, Guo IC et al (2002) Molecular characterization and pathogenicity of a grouper iridovirus (GIV) isolated from yellow grouper, Epinephelus awoara (Temminck \& Schlegel). J Fish Dis 25:91-100 
Neal JW, Eggleton MA, Goodwin AE (2009) The effects of largemouth bass virus on a quality largemouth bass population in Arkansas. J Wildl Dis 45:766-771

O'Bryan CJ, Gray MJ, Brooks CS (2012) Further presence of ranavirus infection in amphibian populations of Tennessee, USA. Herpetol Rev 43:293-295

OIE (2008) Aquatic animal health code. Section 2.4 diseases of amphibians. http://www.oie.int/ international-standard-setting/aquatic-code/. Accessed 20 March 2014

Paetow LJ, Pauli BD, McLaughlin JD et al (2011) First detection of ranavirus in Lithobates pipiens in Quebec. Herpetol Rev 42:211-214

Pasmans F, Blahak S, Martel A et al (2008) Ranavirus-associated mass mortality in imported red tailed knobby newts (Tylototriton kweichowensis): a case report. Vet J 175:257-259

Pearman PB, Garner TWJ (2005) Susceptibility of Italian agile frog populations to an emerging strain of Ranavirus parallels population genetic diversity. Ecol Lett 8:401-408

Pearman PB, Garner TWJ, Straub M et al (2004) Response of the Italian agile frog (Rana latastei) to a Ranavirus, frog virus 3: a model for viral emergence in naïve populations. J Wildl Dis 40:660-669

Petranka JW, Murray SM, Kennedy CA (2003) Response of amphibians to restoration of a southern Appalachian wetland: perturbations confounded post-restoration assessment. Wetlands 23:278-290

Picco AM, Collins JP (2008) Amphibian commerce as a likely source of pathogen pollution. Conserv Biol 22:1582-1589

Picco AM, Brunner JL, Collins JP (2007) Susceptibility of the endangered California tiger salamander, Ambystoma californiense, to Ranavirus infection. J Wildl Dis 43:286-290

Picco AM, Karam AP, Collins JP (2010) Pathogen host switching in commercial trade with management recommendations. Ecohealth 7:252-256

Plumb JA, Hanson LA (2011) Health maintenance and principal microbial diseases of cultured fishes. Wiley, Hoboken

Plumb JA, Zilberg D (1999a) Survival of largemouth bass iridovirus in frozen fish. J Aquat Anim Health 11:94-96

Plumb JA, Zilberg D (1999b) The lethal dose of largemouth bass virus in juvenile largemouth bass and the comparative susceptibility of striped bass. J Aquat Anim Health 11:246-252

Plumb JA, Grizzle JM, Young HE et al (1996) An iridovirus isolated from wild largemouth bass. J Aquat Anim Health 8:265-270

Plumb JA, Noyes AD, Graziono S et al (1999) Isolation and identification of viruses from adult largemouth bass during a 1997-1998 survey in the southeastern United States. J Aquat Anim Health 11:391-399

Pozet F, Morand M, Moussa A et al (1992) Isolation and preliminary characterization of a pathogenic icosahedral deoxyribovirus from the catfish Ictalurus melas. Dis Aquat Organ $14: 35-42$

Prasankok P, Chutmongkonkul M, Kanchankhan S (2005) Characterization of iridovirus isolated from diseased marbled sleepy goby, Oxyeleotris marmoratus. In: Walker PJ, Lester RG, Bondad-Reantaso M (eds) Diseases in Asian Aquaculture V. Asian Fisheries Society, Manila

Price, SJ, Garner TWJ, Nichols RA, et al. (2014) Collapse of amphibian communities due to an introduced Ranavirus. Curr Biol 24:2586-2591. http://www.cell.com/current-biology/pdfExtended/S0960-9822(14)01149-X

Qin QW, Chang SF, Ngoh-lim GH et al (2003) Characterization of a novel ranavirus isolated from grouper Epinephelus tauvina. Dis Aquat Organ 53:1-9

Richter SC, Drayer AN, Strong JR et al (2013) High prevalence of ranavirus infection in permanent constructed wetlands in eastern Kentucky, USA. Herpetol Rev 44:464-466

Ridenhour BJ, Storfer AT (2008) Geographically variable selection in Ambystoma tigrinum virus (Iridoviridae) throughout the western USA. J Evol Biol 21:1151-1159

Rothermel BR, Travis ER, Miller DL et al (2013) High occupancy of stream salamanders despite high Ranavirus prevalence in a southern Appalachians watershed. Ecoheath 10:184-189

Ruder MG, Allison AB, Miller DL et al (2010) Pathology in practice. J Am Vet Med Assoc 237:783-785 
Russell DM, Goldberg CS, Sprague L et al (2011) Ranavirus outbreaks in amphibian populations of northern Idaho. Herpetol Rev 42:223-225

Schloegel LM, Picco AM, Kilpatrick AM et al (2009) Magnitude of the US trade in amphibians and presence of Batrachochytrium dendrobatidis and ranavirus infection in imported North American bullfrogs (Rana catesbeiana). Biol Conserv 142:1420-1426

Schloegel LM, Daszak P, Cunningham AA et al (2010) Two amphibian diseases, chytridiomycosis and ranaviral disease, are now globally notifiable to the World Health Organization for Animal Health (OIE): an assessment. Dis Aquat Organ 92:101-108

Schock DM, Bollinger TK, Chinchar VG et al (2008) Experimental evidence that amphibian ranaviruses are multi-host pathogens. Copeia 1:133-143

Schock DM, Ruthig GR, Collins JP et al (2010) Amphibian chytrid fungus and ranaviruses in the Northwest Territories, Canada. Dis Aquat Organ 92:231-240

Schramm HL Jr, Davis JG (2006) Survival of largemouth bass from populations infected with largemouth bass virus and subjected to simulated tournament conditions. N Am J Fish Manag 26:826-832

Sharifian-Fard M, Pasmans F, Adriaensen C et al (2011) Ranaviruses in invasive bullfrogs, Belgium. Emerg Infect Dis 17:2371-2372

Shaver K (2012) In Md., fear for the turtles. http://www.washingtonpost.com/local/commuting/2012/02/01/gIQA5O0Z9Q_story.html. Accessed 31 July 2014

Sim RR, Wack AN, Allender AC, Murphy KJ, Bronson E (2012) Management of a concurrent ranavirus and herpesvirus epizootic event incaptive eastern box turtles (Terrapene carolina carolina). Proceedings Association of Reptilian and Amphibian Veterinarians

Southard GM, Fries LT, Terre DR (2009) Largemouth bass virus in Texas: distribution and management issues. J Aquat Anim Health 21:36-42

Souza MJ, Gray MJ, Colclough P et al (2012) Prevalence of infection by Batrachochytrium dendrobatidis and Ranavirus in eastern Hellbenders (Cryptobranchus alleganeiensis alleganeiensis). J Wildl Dis 48:560-566

Speare R, Smith JR (1992) An iridovirus-like agent isolated from the ornate burrowing frog, Limnodynastes in northern Australia. Dis Aquat Organ 14:51-57

Speare R, Freeland WJ, Bolton SJ (1991) A possible iridovirus in erythrocytes of Bufo marinus in Costa Rica. J Wildl Dis 27:457-462

St Amour V, Wong WM, Garner TWJ et al (2008) Anthropogenic influence on prevalence of 2 amphibian pathogens. Emerg Infect Dis 12:1175-1176

Stark T, Laurijssens C, Weterings M et al (2014) Death in the clouds: Ranavirus associated mortality in an assemblage of cloud forest amphibians in Nicaragua. Acta Herpetol 9:125-127

Stöhr AC, Hoffmann A, Papp T et al (2013a) Long-term study of an infection with ranaviruses in a group of edible frogs (Pelophylax kl. esculentus) and partial characterization of two viruses based on four genomic regions. Vet J 197:238-244

Stöhr AC, Blahak S, Heckers KO et al (2013b) Ranavirus infections associated with skin lesions in lizards. Vet Res 44:84

Stöhr AC, Fleck J, Mutchmann F et al (2013c) Ranavirus infection in a group of wild caught Lake Urmia newts Neurergus crocatus importuned from Iraq to Germany. Dis Aquat Organ 103:185-189

Stöhr AC, Heckers KO, Ball L et al (2013d) Coinfection with multiple viruses in European pond turtles (Emys orbicularis). In: Proceedings of Association of Reptilian and Amphibian Veterinarians, Indianapolis

Stöhr AC, López-Bueno A, Blahak S, Caeiro MF, Rosa GM, et al. (2015) Phylogeny and Differentiation of Reptilian and Amphibian Ranaviruses Detected in Europe. PLoS ONE 10(2): e0118633. doi:10.1371/journal.pone.0118633

Storfer A, Alfaro ME, Ridenhour BJ et al (2007) Phylogenetic concordance analysis shows an emerging pathogen is novel and endemic. Ecol Lett 10:1075-1083

Tapiovaara H, Olesen NJ, Linden J et al (1998) Isolation of an iridovirus from pike-perch Stizostedion lucioperca. Dis Aquat Organ 32:185-193 
Teacher AGF, Cunningham AA, Garner TWJ (2010) Assessing the long-term impacts of Ranavirus infection on wild common frog populations. Anim Conserv 13:514-522

Todd-Thompson M (2010) Seasonality, variation in species prevalence and localized disease for ranavirus in Cades Cove (Great Smoky Mountains National Park) amphibians. M.Sc. Thesis, University of Tennessee, Knoxville

Torrence SM, Green DE, Benson CJ et al (2010) A new ranavirus isolated from Pseudacris clarkii tadpoles in Playa wetlands in the southern High Plains, Texas. J Aqaut Anim Health 22:65-72

Une Y, Nakajinma K, Taharaguchi S et al (2009a) Ranavirus infection outbreak in the salamander (Hynobius nebulosus) in Japan. J Comp Pathol 141:310

Une Y, Sakuma A, Matsueda H et al (2009b) Ranavirus outbreak in North American bullfrogs (Rana catesbeiana), Japan. Emerg Infect Dis 15:1146-1147

USFWS (2011) National wild fish health survey database. USFWS, Washington, DC. www.fws. gov/wildfishsurvey/database/nwfhs. Accessed 20 May 2014

USGS 2005. USGS National Wildlife Health Center Quarterly Wildlife Mortality ReportApril 2005 to June 2005. http://www.nwhc.usgs.gov/publications/quarterly_reports/2005_qtr_2.jsp

USGS 2008. USGS National Wildlife Health Center Quarterly Wildlife Mortality ReportOctober 2008 to December 2008 http://www.nwhc.usgs.gov/publications/quarterly_reports/2008_qtr_4.jsp

Uyehara IK, Gamble T, Cotner S (2010) The presence of Ranavirus in anuran populations at Itasca State Park, Minnesota, USA. Herpetol Rev 41:177-179

Waltzek TB, Miller DL, Gray MJ et al (2014) New disease records for hatchery-reared sturgeon: expansion of host range of frog virus 3 into pallid sturgeon, Scaphirhynchus albus. Dis Aquat Organ 111(3):219-227

Weir RP, Moody NJG, Hyatt AD (2012) Isolation and characterization of a novel Bohle-like virus from two frog species in the Darwin rural area, Australia. Dis Aquat Organ 99:169-177

Weng SP, He JG, Wang XH et al (2002) Outbreaks of an iridovirus disease in cultured tiger frog, Rana tigrina rugulosa, in southern China. J Fish Dis 25:423-427

Westhouse RA, Jacobson ER, Harris RK et al (1996) Respiratory and pharyngo-esophageal iridovirus infection in a gopher tortoise (Gopherus polyphemus). J Wildl Dis 32:682-686

Whitfield SM, Geerdes E, Chacon I et al (2013) Infection and co-infection by the amphibian chytrid fungus and ranavirus in wild Costa Rican frogs. Dis Aquat Organ 104:173-178

Whittington RJ, Reddacliff GL (1995) Influence of environmental temperature on experimental infection of redfin perch (Perca fluviatilis) and rainbow trout (Oncorhynchus mykiss) with epizootic haematopoietic necrosis virus, an Australian iridovirus. Aust Vet J 72:421-424

Whittington RJ, Philbey A, Reddacliff GL et al (1994) Epidemiology of epizootic haematopoietic necrosis virus (EHNV) infection in farmed rainbow trout, Oncorhynchus mykiss (Walbaum): findings based on virus isolation, antigen capture ELISA and serology. J Fish Dis 17:205-218

Whittington RJ, Kearns C, Hyatt AD et al (1996) Spread of epizootic haematopoietic necrosis virus (EHNV) in redfin perch (Perca fluviatilis) in southern Australia. Aust Vet J 73:112-114

Whittington RJ, Reddacliff LA, Marsh I et al (1999) Further observations on the epidemiology and spread of epizootic haematopoietic necrosis virus (EHNV) in farmed rainbow trout Oncorhynchus mykiss in southeastern Australia and a recommended sampling strategy for surveillance. Dis Aquat Organ 35:125-130

Whittington RJ, Becker JA, Dennis MM (2010) Iridovirus infections in finfish-critical review with emphasis on ranaviruses. J Fish Dis 33:95-122

Wolf K, Bullock GL, Dunbar CE et al (1969) Tadpole edema virus: a viscerotropic pathogen for anuran amphibians. J Infect Dis 118:253-262

Woodland JE, Brunner CJ, Noyes AD et al (2002a) Experimental oral transmission of largemouth bass virus. J Fish Dis 25:669-672

Woodland JE, Noyes AD, Grizzle JM (2002b) A survey to detect largemouth bass virus among fish from hatcheries in the southeastern USA. Trans Am Fish Soc 131:308-311

Xu K, Zhu D, Wei Y et al (2010) Broad distribution of ranavirus in free-ranging Rana dybowskii, in Heilongjiang, China. Ecohealth 7:18-23 
Zhang Q, Li Z, Jiang Y et al (1996) Preliminary studies on virus isolation and cell infection from diseased frog Rana grylio. Acta Hydrobiol Sin 4:390-392

Zhang QY, Xiao F, Li ZQ et al (2001) Characterization of an iridovirus from the cultured pig frog, Rana grylio, with lethal syndrome. Dis Aquat Organ 48:27-36

Zhou ZY, Geng Y, Liu XX et al (2013) Characterization of a ranavirus isolated from the Chinese giant salamander (Andrias davidianus, Blanchard, 1871) in China. Aquaculture 384387:66-73

Zilberg D, Grizzle JM, Plumb JA (2000) Preliminary description of lesions in juvenile largemouth bass injected with largemouth bass virus. Dis Aquat Organ 39:143-146

Zupanovic Z, Lopez G, Hyatt AD et al (1998a) Giant toads, Bufo marinus, in Australia and Venezuela have antibodies against ranaviruses. Dis Aquat Organ 32:1-8

Zupanovic Z, Musso C, Lopez G et al (1998b) Isolation and characterization of iridoviruses from the giant toad Bufo marinus in Venezuela. Dis Aquat Organ 33:1-9 